\title{
Enantioselective reduction of ketophosphonates using adducts of chiral natural acids with sodium borohydride
}

\author{
E.V. Gryshkun, V. Nesterov, and O. I. Kolodyazhnyi* \\ Institute of Bioorganic Chemistry and Petrochemistry, National Academy of Science of \\ Ukraine,ul. Murmanskaya 1, Kiev 02094, Ukraine \\ E-mail: olegkol321@rambler.ru
}

Dedicated to Prof. Pawel Kafarski to honor the achievements within his career

\begin{abstract}
A method for asymmetric reduction of $\alpha$ - and $\beta$-ketophosphonates using chiral complexes prepared from sodium borohydride and natural aminoacids or tartaric acids was developed. Reduction of $\alpha$ - or $\beta$-ketophosphonates by these reagents led to formation of chiral $(S)$ - or $(R)$ hydroxyphosphonates. Reduction of chiral di- $(1 R, 2 S, 5 R)$-menthylketophosphonates by the chiral complexes $\mathrm{NaBH}_{4} /(R, R)$-proline or $\mathrm{NaBH}_{4} /(R, R)$-tartaric acid due to the double matched asymmetric induction resulted in increased stereoselectivity of the reaction and led to the formation of hydroxyphosphonates up to $90 \%$ ee or higher. Dimenthyl 2-hydroxy-3chloropropylphosphonate was utilized as a chiron for the preparation of a number of biologically active compounds in multigram quantity.
\end{abstract}

Keywords: Asymmetric synthesis, asymmetric reduction, hydroxyphosphonates, ketophosphonates, L-prolin, tartaric acid

\section{Introduction}

Hydroxyphosphonic acids are an important class of compounds occurring in nature. ${ }^{1}$ Many of these compounds have attracted considerable attention in recent years for their role in biologically relevant processes. ${ }^{1-3}$ They possess antibacterial, antiviral, antibiotic, pesticidal, anticancer, and enzyme inhibitor properties. ${ }^{1,2}$ In our previous publications we have reported methods for the preparation of optically active $\alpha$ - and $\beta$-hydroxyphosphonic acids, including efficient methods for the enantioselective reduction of ketophosphonates. ${ }^{2-4}$ The previously employed methods provide access to many $\alpha$-hydroxyphosphonates, but the use of chiral auxiliaries and/or catalysts is required to improve the stereoselectivity of these methods. A 
possible method for the stereoselective introduction of the hydroxyl group is a stereoselective reduction of prochiral keto compounds.

The asymmetric reduction of ketophosphonates has been studied earlier. It included reduction with borane or catecholborane in the presence of chiral oxazaborolydine catalysts, ${ }^{6}$ reduction with chiral chlorodiisopynacampheylboranes ${ }^{7}$ and enantioselective hydrogenation in the presence of chiral BINAP-ruthenium(II) catalyst $^{8}$ (BINAP $=2,2^{\prime}$-bis(diphenylphosphino)1,1'-binaphthyl). However all these methods require application of expensive reagents and specific reaction conditions which often are too complicated to be reproduced.

The asymmetric reduction can occur under the control of chiral auxiliaries, which are included in the ketophosphonate, under the control of asymmetric catalysts, or chiral reagents. The reduction of diethyl $\alpha$-ketophosphonates ${ }^{9}$ with borane in the presence of chiral $\beta$-butyloxazoborolidines as a catalyst yielded $(S)$ - or $(R)$-diethyl 1-hydroxyalkylphosphonates in good yields and moderate enantiomeric excesses $(53-83 \%$ ee $) .{ }^{10}$ Acylphosphonic and bisacylphosphonic acid sodium salts were directly reduced by sodium borohydride to the corresponding hydroxyphosphonates and dihydroxy-alkanebisphosphonates. ${ }^{11}$ The reduction of $\left[\left(N\right.\right.$-p-toluenesulfonyl) amino]- $\beta$-ketophosphonates ${ }^{12}$ with different borohydrides gave [ $(N$-ptoluenesulfonyl)amino]- $\beta$-hydroxyphosphonates in good chemical yields and moderate diastereoselectivity. Only the zinc borohydride reduction of ketophophonates resulted in the formation of hydroxy-aminophosphonates with good diastereoselectivity. ${ }^{13}$

For these reasons, in continuation of our studies on application of available natural compounds as the reagents in asymmetric synthesis, ${ }^{14-16}$ we attempted to find simple procedures for the reduction of the ketophosphonates with chiral reagents prepared on the basis of sodium borohydride and the chiral natural acids such as tartaric acid or aminoacid proline.

\section{Results and Discussion}

The reduction of ketophosphonates $\mathbf{1 , 2}$ with sodium borohydride proceeds with low stereoselectivity $(\sim 30-35 \% \mathrm{de}) .{ }^{17}$ Therefore we have tried to increase the stereoselectivity via the complexation of sodium borohydride with chiral natural acids (Scheme 1). ${ }^{15}$

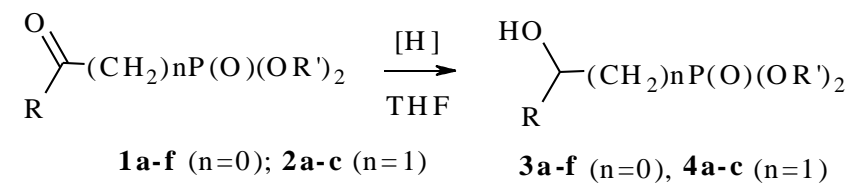

$\mathrm{R}=\mathrm{Ph}, \mathrm{R}^{\prime}=\mathrm{Mnt}, \mathrm{n}=0(\mathbf{1 , 3} \mathbf{a}) ; \mathrm{R}=\mathrm{C}_{6} \mathrm{H}_{4} \mathrm{~F}-4, \mathrm{R}^{\prime}=\mathrm{Mnt}, \mathrm{n}=0(\mathbf{1 , 3} \mathbf{b}) ; \mathrm{R}=\mathrm{C}_{6} \mathrm{H}_{4} \mathrm{OMe}-2(2-\mathrm{An})$, $\mathrm{R}^{\prime}=$ Mnt, $\mathrm{n}=0$ (1,3 c); R= i-Pr, R'= Mnt, n=0 (1,3 d); R= Pyperonyl, R'= Mnt, n=0 (1,3 e); R = $\mathrm{Ph}, \mathrm{R}^{\prime}=\mathrm{Et}, \mathrm{n}=0(\mathbf{1 , 3} \mathbf{f}) ; \mathrm{R}=\mathrm{CH}_{2} \mathrm{Cl}, \mathrm{R}^{\prime}=\mathrm{Et}, \mathrm{n}=1(\mathbf{2 , 4} \mathbf{a}) ; \mathrm{R}=\mathrm{CH}_{2} \mathrm{Cl}, \mathrm{R}{ }^{\prime}=\mathrm{Mnt}, \mathrm{n}=1(\mathbf{2 , 4} \mathbf{b}), \mathrm{R}$ $=\mathrm{Ph}, \mathrm{R}^{\prime}=\mathrm{Et}, \mathrm{n}=1(\mathbf{2 , 4} \mathrm{c})$;

Scheme 1 
In this article we have tested natural amino acids: L-alanine (Ala), L-leucine (Leu), Lproline (Pro), and hydroxycarbonic acids: L-(+)-tartaric acid (L-TA), D-(-)-tartaric acid (D-TA), $(S)$-malic acid (Mal) as chiral auxiliaries in the reaction of ketophosphonates with sodium borohydride (Scheme 2).
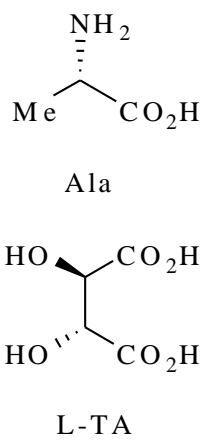

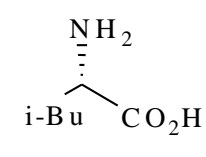

L eu<smiles>O=C(O)[C@H](O)[C@@H](O)C(=O)O</smiles>

D-T A<smiles>O=C(O)[C@@H]1CCCN1</smiles>

Pro<smiles>O=C(O)C[C@H](O)C(=O)O</smiles>

Mal

\section{Scheme 2}

The best results in improving of stereoselectivity of ketophosphonate reduction were attained with chiral complex of sodium borohydride with natural amino acid - L-proline $\left(\mathrm{NaBH}_{4}\right.$ Pro) (Scheme 3). At the same time P-alanine and L-leucine showed moderate stereoselectivity (See Table 1). For the preparation of this reducing reagent, an equimolar amount of L-proline was added to sodium borohydride suspended in THF, and the mixture was stirred at room temperature for several hours. ${ }^{18}$.

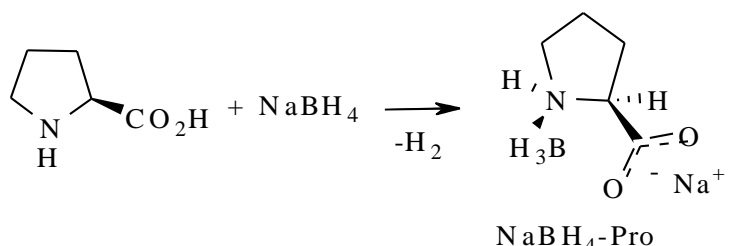

\section{Scheme 3}

The ketophosphonates 3a-c were then added to $\mathrm{NaBH}_{4}$-Pro, resulting in the formation of (S)-hydroxyphosphonate with a stereoselectivity in the range from 52\% to $79 \%$ de purity (Method a). Compounds $(S)-3 a-c$ were crystallized from hexane and isolated in approximately $100 \%$ optical purity (Scheme 4) The chiral menthyl groups of 3a-c were cleaved off under mild conditions by a modified procedure of Morita et al. ${ }^{19}$ The reaction of the dimenthyl $\alpha$ hydroxyphosphonates 3a-c with trimethylsilyl chloride and $\mathrm{NaI}$ in acetonitrile led to bis(trimethysilyl)- $\alpha$-hydroxyphosphonates, which were finally hydrolyzed in amixture of water/ethanol to afford the optically active $\alpha$-hydroxyphosphonic acids $\mathbf{5 a}-\mathbf{c}$. The treatment of $\alpha$ hydroxyphosphonates 3a-c with hydrochloric acid in water/dioxane solution also gave the 
corresponding free optically active phosphonic acids $\mathbf{5 a - c}$ in good yields. Owing to the steric hindrance of the esters 1a-c, it was necessary to use longer reaction times and higher temperatures ketophosphonates with sodium borohydride (Scheme 4).

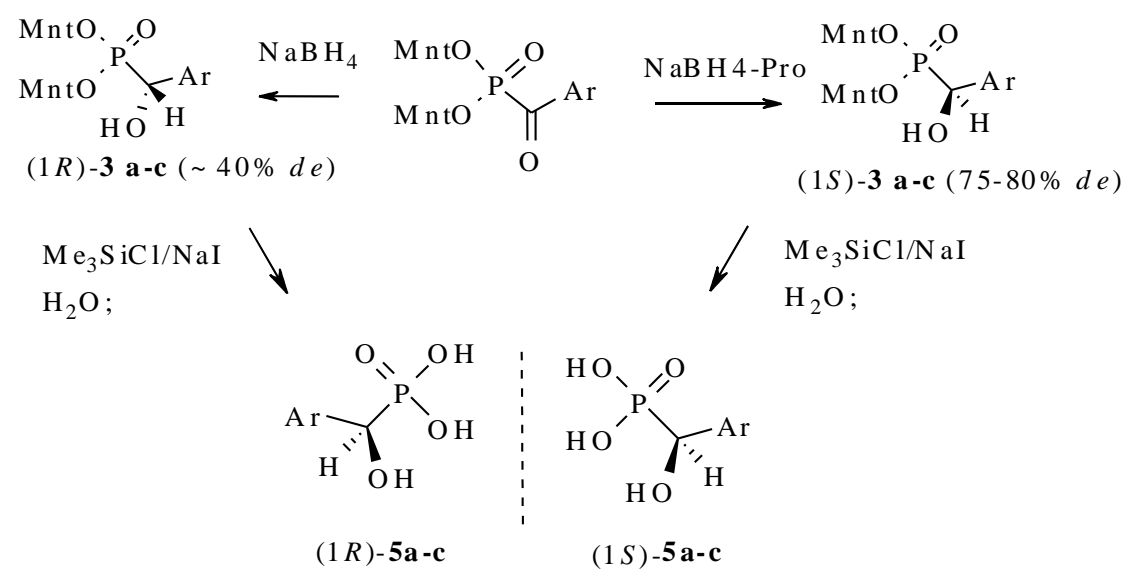

\section{Scheme 4}

Compounds 3 and 5 were identified by ${ }^{1} \mathrm{H},{ }^{13} \mathrm{C}$, and ${ }^{31} \mathrm{P}$ NMR spectroscopy and liquid chromatography. Dimenthyl $\alpha$-hydroxyphosphonates are easily crystallizable compounds, which are obtained in a stereochemically pure state.

${ }^{31} \mathrm{P}$ NMR spectra of compounds $\mathbf{3 a}-\mathbf{c}$ show signals for the two diastereomers, with $\delta_{\mathrm{P}}$ values in the area of $21.0-21.5 \mathrm{ppm}$, The downfield signal belongs to the $(R)$-diastereomer and the upfield signal to the $(S)$-diastereomer of $\alpha$-hydroxyphosphonates 3 . ${ }^{1} \mathrm{H}$ NMR spectra of compounds 3a-c revealed that the signals belong to the protons of the menthyl group, aromatic protons of appropriate multiplicity and intensity, a broad signal due to the $\mathrm{OH}$ group at $\delta_{\mathrm{H}}=3.7$ ppm, and a $\mathrm{CH}$ doublet at $\delta_{\mathrm{H}}=4.9 \mathrm{ppm} .{ }^{1} \mathrm{H}$ and ${ }^{13} \mathrm{C}$ NMR spectra of compounds $\mathbf{3 a}-\mathbf{c}$ indicate that the molecules are asymmetric, because the signals of the two menthyl groups bonded to phosphorus are magnetically nonequivalent. The configuration of $(R)-(+)-\alpha-$ hydroxybenzylphosphonic acid 5a was confirmed by comparing its optical rotation with literature data. $^{20}$

The reduction of dimenthyl ketophosphonates with $\mathrm{NaBH}_{4}$ led preferably to the formation of $(R)$ - $\alpha$-hydroxyphosphonates, whereas the reduction with $\mathrm{NaBH}_{4}$-Pro furnishes $(S)$ hydroxyphosphonates.

The preferential formation of $(R)$-diastereomers observed in the reduction of $\alpha$ ketophosphonates 1 with $\mathrm{NaBH}_{4}$ in ethanol can be anticipated to some extent by examining their molecular models. The molecular structures of $\alpha$-ketophosphonate 1a and $\alpha$-hydroxyphosphonate 3b indicate the high asymmetry of the molecules owing to a propeller-like arrangement of the menthyl groups around the phosphorus atom. Thus, one can make the reasonable assumption that the attack of the reducing agent on the carbonyl group will take place preferentially from the side leading to the $(R)$-configuration rather than from the opposite side, which is shielded by the 
menthyl group (Figure 1, left). This corresponds to an approach to the more exposed face of the $\alpha$ - ketophosphonate. The selectivity of the reduction with $\mathrm{NaBH}_{4}$-Pro depends upon the geometry of the complex formed by coordination of the carbonyl oxygen to the boron atom and of the carboxylic sodium to the oxygen of the P-O group. The reaction cycle inside the favored intermediate complex is shown in Fig. 1, right. It is evident that in this case the attack of the chiral reducing agent on the carbonyl group will take place preferentially from the side leading to the $(S)$ - configuration rather than the opposite $R e$ side. In summary, the described asymmetric reduction of dimenthyl $\alpha$-ketophosphonates provides an easy route to both stereoisomers of optically active $\alpha$-hydroxyphosphonic acids in good yield and in enantiomeric excess.
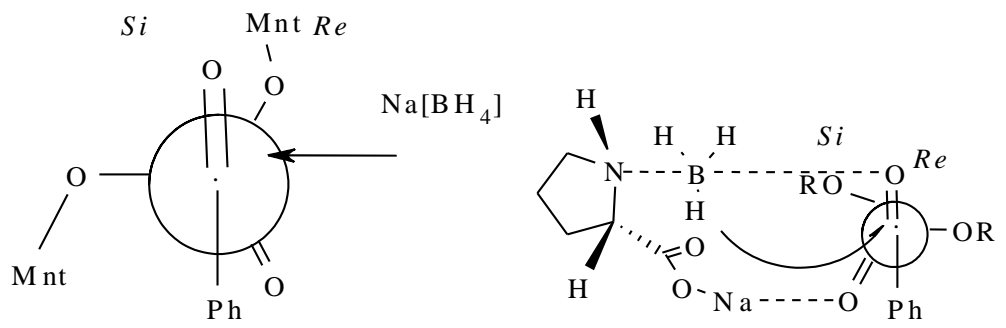

Figure 1. Facial attack on the $\alpha$-phenylketophosphonate carbonyl group by $\mathrm{NaBH}_{4}$ (left) and $\mathrm{NaBH}_{4}$-Pro (right).

We succeeded in the further improvement of the stereoselectivity of ketophosphonate hydroborination when used chiral complex of sodium borohydride with natural $(R, R)$-(+)-tartaric acids. $^{21,22}$ This reducing reagent was prepared by mixing sodium borohydride with tartaric acids in 1:1 ratio in THF followed by refluxing the mixture. After removing the solvent the adduct could be isolated as a colorless fine crystalline substance with high melting point $\left(>250^{\circ} \mathrm{C}\right)$. The compound is very hygroscopic and reacts with water. It contains coordinatively bonded THF $(0.5$ equv.) as confirmed by ${ }^{1} \mathrm{H}$ NMR spectrum which contains a multiplet at $1.7 \mathrm{ppm}\left(\mathrm{CH}_{2} \mathrm{C}\right)$, a multiplet at $3.7 \mathrm{ppm}\left(\mathrm{CH}_{2} \mathrm{O}\right)$ and a multiplet at $4.5 \mathrm{ppm}(\mathrm{CHOH})$. Detailed study of structure is restricted due to its low solubility in ordinary organic solvents. Note that compounds obtained by treatment of sodium borohydride with achiral carboxylic acids (acetic or trifluoroacetic) to which structure of $\mathrm{Na}\left[\mathrm{BH}(\mathrm{OAc})_{3}\right]$ or $\mathrm{Na}\left[\mathrm{BH}_{2}(\mathrm{OAc})_{2}\right]$ (depending on the initial reagent ratio) is assigned are well known and are used as reducing reagents in organic synthesis (Scheme 5). ${ }^{23}$

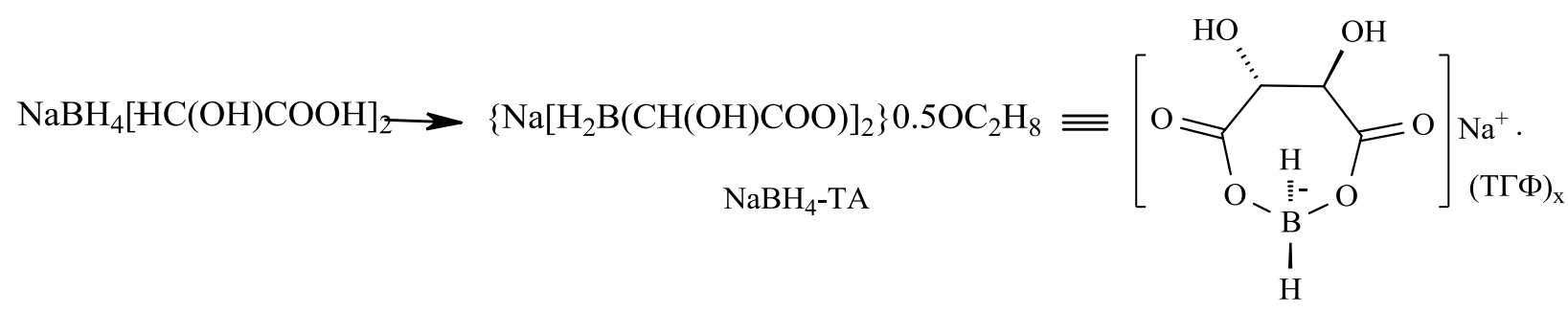

\section{Scheme 5}


Reduction of ketophosphonates 3,4 with the reagent was performed at cooling to $-30^{\circ} \mathrm{C}$ in THF (Method b) . Reduction of diethyl $\alpha$-ketophosphonates with the $\mathrm{NaBH}_{4}-(R, R)$-TA chiral reagent yielded diethyl ( $1 S)$ - $\alpha$-hydroxybenzylphosphonates with optical purity $60 \%$, while reduction of dimenthyl ketophosphonates led to formation of (1S)$\alpha$-hydroxybenzylphosphonates 3 with diastereomeric purity up to $80-93 \%$ de (Table 1 and Scheme 6).

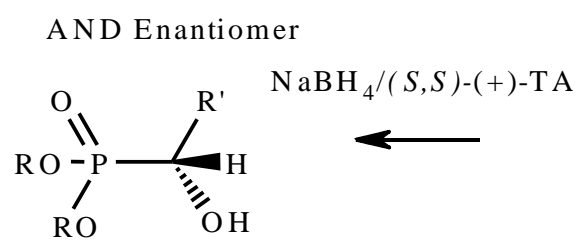

(R)-3a-f

AND Enantiomer

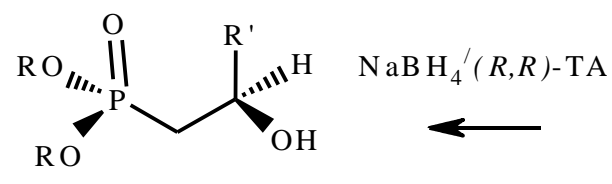

( $2 S)-\mathbf{4 a - c}$

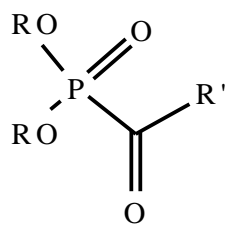

1 a-f

AND Enantiomer

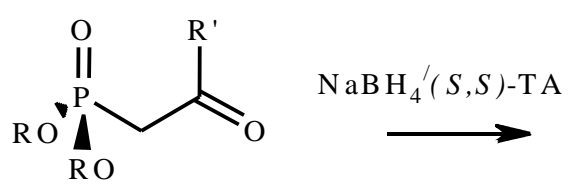

2a-c
AND Enantiomer
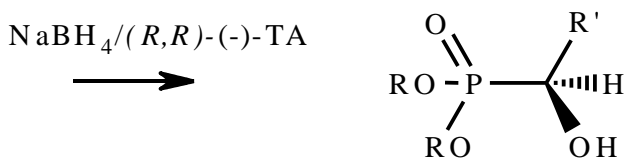

( $S$ )-3 a-f

AND Enantiomer

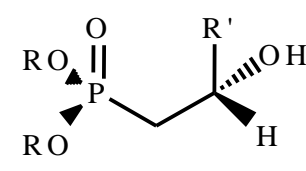

$(2 R)-\mathbf{4 a - c}$

TA - Tartaric Acid;

\section{Scheme 6}

The higher stereoselectivity of reduction in the case of dimenthyl arylketophosphonates we explain by the effect of double asymmetric induction, ${ }^{24}$ because here the asymmetric inductions due to menthyl groups supplementes that of tartaric acid. At the same time, reduction of dimenthyl ketophosphonates with the sodium borohydride $(S, S)$ - tartaric acid reagent resulted in lower stereoselectivity. For example, reduction of dimenthyl 1-oxobenzylphosphonate yielded corresponding hydroxyphosphonate with $45 \% \mathrm{de}$. It is obviously that asymmetric inductions due to $(1 R, 2 S, 5 R)$-menthyl groups and $(R, R)$-tartaric acids are compatible and therefore are summated and increase the total stereoselectivity. On the other hand, asymmetric inductions of $(1 R, 2 S, 5 R)$-menthyl groups and $(S, S)$-tartaric acid act in opposite directions and diminish resulting stereoselectivity. The reduction of chiral di( $1 R, 2 S, 5 R)$-dimenthyl ketophosphonate $\mathbf{2 b}$ with the chiral complex $(R, R)-\mathrm{TA} / \mathrm{NaBH}_{4}$ proceeded under control of double stereoselectivity to yield the $(S)$ - $\beta$-hydroxyphosphonate $\mathbf{4 b}$ with $96 \%$ de that was considerably higher than the single stereoselectivity when the achiral diethyl 2-keto-3-chloropropylphosphonate 2a was reduced with $(R, R)-\mathrm{TA} / \mathrm{NaBH}_{4}$ with $80 \%$ ee (Table 2). 
Table 1. Asymmetric reduction of ketophosphonates to hydroxyphosphonates

\begin{tabular}{|c|c|c|c|c|c|c|c|c|}
\hline Entry & Comp-d & $\mathrm{R}$ & $\mathrm{R}^{\prime}$ & $\mathrm{n}$ & $\begin{array}{c}\text { Yield } \\
(\%)\end{array}$ & $\begin{array}{c}\text { Auxiliary } \\
\text { (A) }\end{array}$ & $\begin{array}{c}\text { Config of } \\
\mathbf{3 , 4} \\
\end{array}$ & $e e(\%)$ \\
\hline 1 & $\mathbf{3 a}$ & $\mathrm{Ph}$ & Mnt & 0 & 90 & L-Pro & $S$ & 52.6 \\
\hline 2 & $3 \mathbf{b}$ & $2-\mathrm{F}-\mathrm{C}_{6} \mathrm{H}_{4}$ & Mnt & 0 & 90 & L-Pro & $S$ & 79.2 \\
\hline 3 & $3 c$ & 2-An & Mnt & 0 & 90 & L-Pro & $S$ & 60.6 \\
\hline 4 & 3f & $\mathrm{Ph}$ & $\mathrm{Et}$ & 0 & 85 & L-Leu & - & 21 \\
\hline 5 & $\mathbf{3 a}$ & $\mathrm{Ph}$ & Mnt & 0 & 95 & L-TA & $R$ & 92.4 \\
\hline 6 & $\mathbf{3 a}$ & $\mathrm{Ph}$ & Mnt & 0 & 98 & D-TA & $S$ & 46 \\
\hline 7 & $\mathbf{3 b}$ & $2-\mathrm{F}-\mathrm{C}_{6} \mathrm{H}_{4}$ & Mnt & 0 & 97 & L-TA & $S$ & 80.5 \\
\hline 8 & $3 c$ & 2-An & Mnt & 0 & 96 & L-TA & $S$ & 74 \\
\hline 9 & $3 d$ & i-Pr & Mnt & 0 & 97.6 & L-TA & $S$ & 68 \\
\hline 10 & $3 e$ & Pyperonyl & Mnt & 0 & 97 & L-TA & $S$ & 96 \\
\hline 11 & 3f & $\mathrm{Ph}$ & Et & 0 & 95 & L-TA & $S$ & 60 \\
\hline 12 & 3f & $\mathrm{Ph}$ & Et & 0 & 94 & D-TA & $R$ & 60 \\
\hline 13 & $\mathbf{4 a}$ & $\mathrm{CH}_{2} \mathrm{Cl}$ & $\mathrm{Et}$ & 1 & 86 & L-TA & $S$ & 80 \\
\hline 14 & $\mathbf{4 a}$ & $\mathrm{CH}_{2} \mathrm{Cl}$ & Et & 1 & 82 & D-TA & $R$ & 80 \\
\hline 15 & $\mathbf{4 a}$ & $\mathrm{CH}_{2} \mathrm{Cl}$ & $\mathrm{Et}$ & 1 & 70 & Mal & - & 25 \\
\hline 16 & $4 b$ & $\mathrm{CH}_{2} \mathrm{Cl}$ & Mnt & 1 & 94 & L-TA & $S$ & 96 \\
\hline 17 & $4 b$ & $\mathrm{CH}_{2} \mathrm{Cl}$ & Mnt & 1 & 80 & D-TA & $R$ & 82 \\
\hline 18 & $4 c$ & $\mathrm{Ph}$ & $\mathrm{Et}$ & 1 & 95 & D-TA & $S$ & 44 \\
\hline
\end{tabular}

Table 2. Stereoselectivity of reduction of ketophosphonates

\begin{tabular}{clcccccl}
\hline Entry & $\begin{array}{l}\text { Ketophos- } \\
\text { phonate }\end{array}$ & $\mathrm{R}$ & $\mathrm{R}{ }^{\prime}$ & Config TA & $\begin{array}{c}e e \text { or } d e \\
\text { of } \mathbf{3}\end{array}$ & $\begin{array}{c}\text { Config of } \\
\mathbf{3}\end{array}$ & $\begin{array}{l}\text { Type of } \\
\text { Stereoselectivity }\end{array}$ \\
\hline 1 & $\mathbf{1 f}$ & $\mathrm{Et}$ & $\mathrm{Ph}$ & $\mathrm{NaBH}_{4}$ & 0 & - & - \\
2 & $\mathbf{1 f}$ & $\mathrm{Et}$ & $\mathrm{Ph}$ & $R, R-\mathrm{TA}$ & 82 & $S$ & Single \\
3 & $\mathbf{1 f}$ & $\mathrm{Et}$ & $\mathrm{Ph}$ & $S, S-\mathrm{TA}$ & 78 & $R$ & Single \\
4 & $\mathbf{1 a}$ & $\mathrm{Mnt}$ & $\mathrm{Ph}$ & $\mathrm{NaBH}_{4}$ & 30 & $R$ & Single \\
5 & $\mathbf{1 a}$ & $\mathrm{Mnt}$ & $\mathrm{Ph}$ & $R, R-\mathrm{TA}$ & 92.5 & $S$ & Matched double \\
6 & $\mathbf{1 a}$ & $\mathrm{Mnt}$ & $\mathrm{Ph}$ & $S, S$-TA & 46 & $R$ & Unmatched double \\
\hline
\end{tabular}

Insofar as reduction of ketophosphonates with the complex $\mathrm{NaBH}_{4} /(R, R)$-tartaric acid affords $(S)$-hydroxyphosphonates, it is very probable that $\mathrm{P}=\mathrm{O}$ group is involved to the transition state leading to formation of hydroxyphosphonates as it shown in Figure 2, and promotes stereofacial attack of carbonyl group by hydride ion from the $S i$ side. 


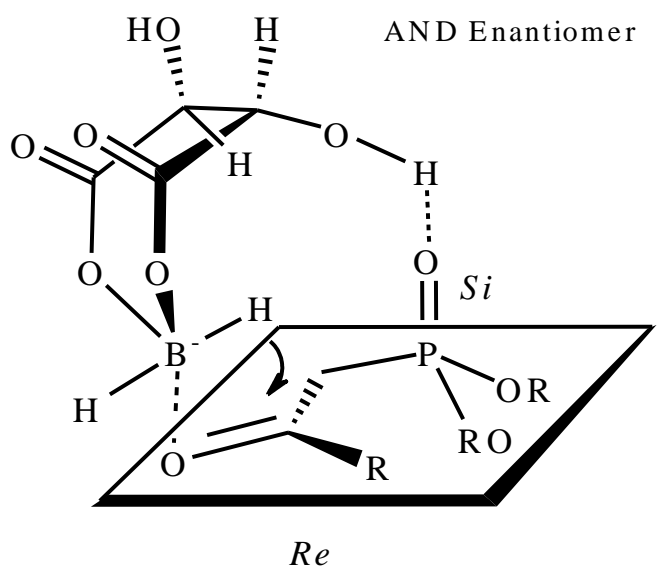

Figure 2. MOPAC-8 stereochemical modeling of reduction of ketophosphonate with $\mathrm{NaBH}_{4} /(\mathrm{R}, \mathrm{R})$-tartaric acid reagent.

Diethyl $\alpha-$ and $\beta$-hydroxyphosphonates were purified by column chromatography. Dimenthyl $\alpha-$ and $\beta$-hydroxyphosphonates were obtained enantiomericaly pure after crystallization from acetonitrile (Table 2).

Several methods were used for elucidation optical purity of the synthesized compounds. The diastereoisomeric ratio of hydroxyphosphonate dimenthyl esters was registered by ${ }^{31} \mathrm{P}-\left\{{ }^{1} \mathrm{H}\right\}$ NMR spectroscopy directly. In the case of homochiral diethyl hydroxyphosphonates the optical purity was determined after derivatization with di-( $1 R, 2 S, 5 R)$-menthyl chlorophosphite resulted in formation of diastereomers of the derivatives with a significant difference in chemical shifts $\delta_{\mathrm{P}}$ in ${ }^{31} \mathrm{P}$ NMR spectra, which provided accurate integration of signals and correct measuring of their diastereomeric ratio. $^{21}$

For determination of optical purity of diethyl hydroxyphosphonates we found convenient to use natural cinchonidine as a chiral solvating reagent. In this case the signals of the hydroxyphosphonate $(R)$ - and $(S)$-enantiomers in ${ }^{31} \mathrm{P}-\left\{{ }^{1} \mathrm{H}\right\} \mathrm{NMR}$ spectra were separated up to zero line and could be easily measured by integration. ${ }^{32,33}$ The absolute configuration of dimenthyl hydroxyphosphonates was determined by the method of chemical extrapolation. The dimenthyl esters were hydrolysed to free hydroxyphosphonic acids whose configuration was determined earlier. ${ }^{25-32}$ For example, the hydrolysis of dimenthyl 2-hydroxy-3chloropropylphosphonate $\mathbf{4 b}$ with conc. hydrochloric acid in dioxane afforded the enantiopure $(S)$-2-Hydroxy-3-chloropropylphosphonic acid $(S)$-6b with high yield.

Stereoisomers of dimenthyl 2-hydroxy-3-chloropropylphosphonate $\mathbf{4 b}$ and 2-hydroxy-3chloropropylphosphonic acid $\mathbf{6 b}$ of high optical purity represent useful chiral synthetic building blocks (chirons) for the synthesis of enantiomerically pure $\beta$-hydroxyphosphonates. By means of these chirons we have earlier obtained biologically important $\beta$-hydroxyphosphonic acids, chiral compounds, $\quad \gamma$-amino- $\beta$-hydroxypropylphosphonic acid (phosphono-GABOB, 7) and phosphono-carnitine 8 in the multigram scale (Scheme 7). ${ }^{14-16,22}$ 


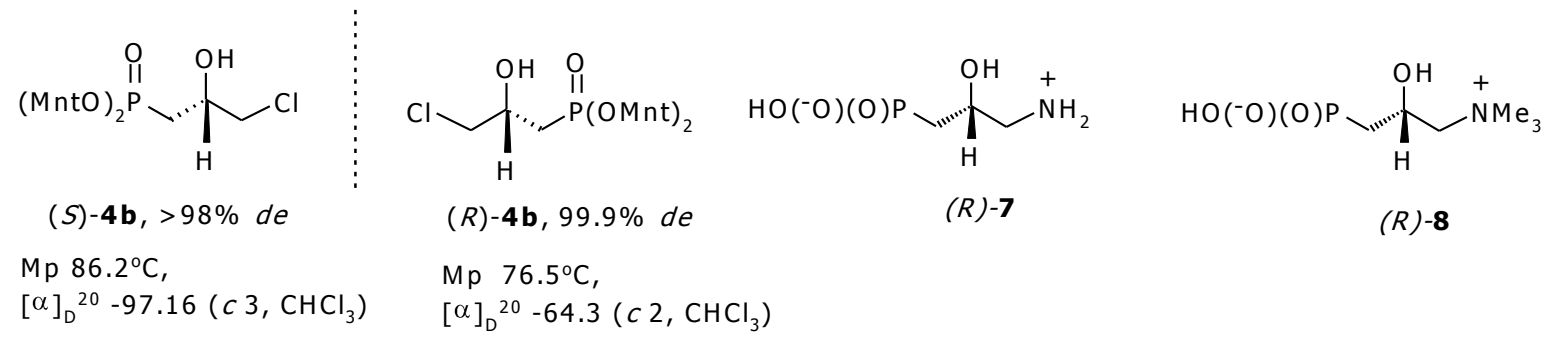

\section{Scheme 7}

The treatment of $(S)$-4a,b bith $\mathrm{K}_{2} \mathrm{CO}_{3}$ in acetonitrile-DMF in the presence of potassium iodide led quantitatively to the formation of epoxide $(R)-\mathbf{9 a}$ with $99 \%$ de. The reaction of epoxide 9a with sodium azide in the presence of ammonium chloride in methanol afforded the (R)-2-hydroxy-3-azidopropylphosphonate 10a in very high yield (Scheme 8). The epoxides 9a,b were converted consequently into azides 10a,b and aziridine $\mathbf{1 2}$.

The diethyl (2R)-2,3-epoxypropylphosphonate $(R)-\mathbf{9 a}, \mathbf{b}$ reacted readily with sodium azide in the presence of ammonium chloride in methanol to afford dialkyl (2R)-2-hydroxy-3azidopropylphosphonates 10a,b. The reaction of azidophosphonates 10a,b with triphenylphosphine at room temperature led at first to the formation of intermediate products 11a,b, bearing pentacoordinated phosphorus, which were registered by ${ }^{31} \mathrm{P}$ NMR spectra. Thus, the ${ }^{31} \mathrm{P}$ NMR spectrum of the product 11a reveals two signals: $\delta_{\mathrm{P}}-55.1$ (pentacoordinated phosphorus) and +26.9 ppm (tetracoordinated phosphorus) of equal intensity according to the structure of this compound. Then, upong heating, 11a converts into triphenylphosphine oxide $\left(\delta_{\mathrm{P}}\right.$ $30.2 \mathrm{ppm})$ and aziridinophosphonate 12a $\left(\delta_{\mathrm{P}} 29 \mathrm{ppm}\right)$, which were isolated in good yields. The diethyl (2S)-aziridine-2-yl-propylphosphonate $(S)$-12a was purified by distillation under vacuum and isolated in pure state as colorless liquid

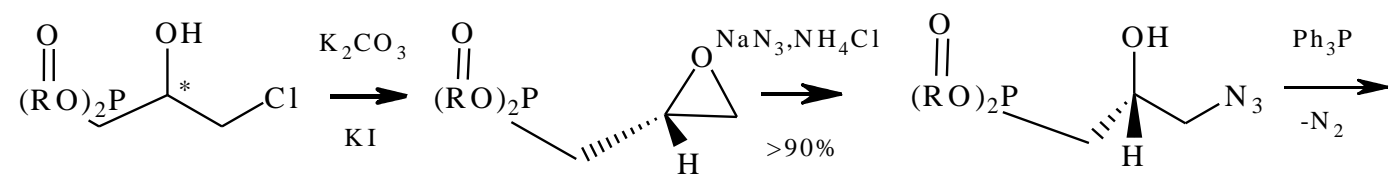
$4 a, b$

9a,b

(R)-10a,b

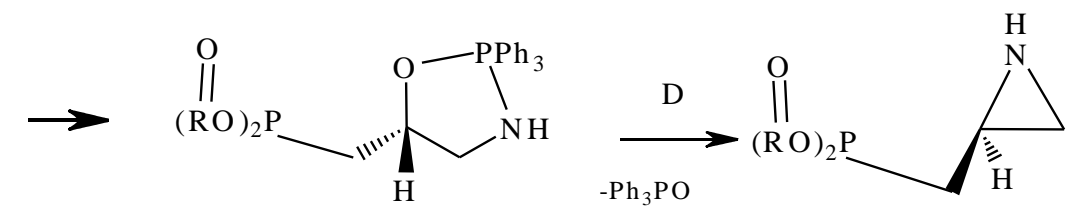

$\mathrm{R}=\mathrm{Et}(\mathrm{a})$, Mnt (b)

$11 \mathbf{a}, \mathbf{b}$

$(S)-\mathbf{1 2 a}$

\section{Scheme 8}


The dimenthyl aziridine-2-yl-propylphosphonate $\mathbf{1 2}$ b was also prepared, however this product contained $\sim 20 \%$ of by-products, which we were not able to separate by column chromatography to obtain this compound in pure state. We are continuing this work with aim to prepare pure $\mathbf{1 2} \mathbf{b}$.

The enantiomeric purity of diethyl $\beta$-hydroxy- $\gamma$-chloropropylphosphonates $\mathbf{4 a}$ was analyzed using cinchonidine as a chiral solvated reagent, ${ }^{33}$ and dimenthylchlorophosphite as a chiral derivatizing reagent. ${ }^{21}$ The ${ }^{1} \mathrm{H}$ NMR spectra of $\beta$-hydroxyphosphonates are of special interest. They disclose signals of diastereotopic protons in $\mathrm{PCH}_{2}$ and $\mathrm{CH}_{2} \mathrm{X}$ groups as doublet doublets due to spin-spin coupling with phosphorus atom, proton of $\mathrm{CHOH}$ group (vicinal constant ${ }^{3} \mathrm{~J}_{\mathrm{HH}}$ ), and due to mutual coupling ${ }^{2} J_{\mathrm{HH}}$. The NMR spectra allows to perform conformational analysis of the obtained compounds. 2-Hydroxy-3-chloropropylphosphonate 4a probably exist mainly as trans-conformers at the $\mathrm{C}_{1}-\mathrm{C}_{2}$ bond, as follows from the values of vicinal constants ${ }^{3} J_{\mathrm{HP}}=18 \mathrm{~Hz}$ and geminal constants ${ }^{3} J_{\mathrm{HH}}$ and ${ }^{3} J_{\mathrm{HH}}$ equal to $15-18 \mathrm{~Hz}$ and $6.3-8.0 \mathrm{~Hz}$, respectively. In the molecules of $\beta$-hydroxyphosphonates probably there is an intramolecular hydrogen bond between hydrogen atom of $\mathrm{CH}-\mathrm{OH}$ group and $\mathrm{P}=\mathrm{O}$ group, in consistence with the downfield shift of the signal of hydroxyl proton to $4.7-5 \mathrm{ppm}$. Stability of the trans-conformers probably is higher due to formation six-membered ring with conformation approaching chair form. In the phosphocarnitine molecule this intramolecular hydrogen bond is probably especially strong, as follows from even greater downfield shift of the signal of $\mathrm{OH}$ proton, to 5-5.1 ppm, because in this case it involves negatively charged oxygen atom in $\mathrm{P}=\mathrm{O}$-group.

\section{Conclusions}

In summary, a series of optically active $\gamma$-amino- $\beta$-hydroxyphosphonic acids can be synthesized starting from the dialkyl $(S)$ - or $(R)$-2-hydroxy-3-chloropropylphosphonates. These compounds give access to $(R)$ - or $(S)$-phosphono-carnitines, phosphono-GABOB, and 2-hydroxy-3aminophosphonates. The described asymmetric reduction of dialkyl $\alpha$ - and $\beta$-ketophosphonates provides an easy route to both stereoisomers of optically active $\alpha$ - and $\beta$-hydroxyphosphonic acids in good yield and in enantiomeric excess. Di(1R,2S,5R)-menthyl $(S)$-2-hydroxy-3cloropropylphosphonate via the formation of the epoxide and reaction with sodium azide was converted into the $(S)$-2-hydroxy-3-azidopropylphosphonate

\section{Experimental Section}

General. Melting points are uncorrected. NMR spectra were registered on a Varian VXR-300 instrument at $300\left({ }^{1} \mathrm{H}\right)$ and $126.16\left({ }^{31} \mathrm{P}\right) \mathrm{MHz}$ with internal TMS $\left({ }^{1} \mathrm{H}\right)$ and external $85 \% \mathrm{H}_{3} \mathrm{PO}_{4}$ in $\mathrm{D}_{2} \mathrm{O}\left({ }^{31} \mathrm{P}\right)$. Optical rotation angles were measured on a Polax-2L polarimeter (Japan) and on a Perkin-Elmer Model 241 spectropolarimeter Column chromatography was performed with 
Merck 60 silica gel. All experiments were performed in inert atmosphere (Ar). For the reaction anhydrous solvents were used: THF was freshly distilled over sodium in the presence of benzophenone, methylene chloride was distilled over $\mathrm{P}_{4} \mathrm{O}_{10}$. The Fluka tartaric acids, sodium borohydride and menthol were used. Tartaric acids and sodium borohydride priory to use were kept for $2 \mathrm{~h}$ in a vacuum at $30{ }^{\circ} \mathrm{C}$.

\section{Reduction of ketophosphonates (1a-c) with $\mathrm{NaBH}_{4}$-Pro by Method a}

To a suspension of sodium borohydride $(0.045 \mathrm{~g}, 1.19 \mathrm{mmol})$ in $8 \mathrm{~mL}$ of THF, L-proline $(0.137$ $\mathrm{g}, 1.19 \mathrm{mmol}$ ) was added. The mixture was stirred at room temperature for 6 to $12 \mathrm{~h}$. Ketophosphonate $1 \mathrm{a}(0.368 \mathrm{~g}, 0.795 \mathrm{mmol})$ was then added, and the mixture was stirred for further $24 \mathrm{~h}$ at room temperature. The solvent was evaporated and $10 \mathrm{~mL}$ of water/ethyl acetate (1:1) mixture was added to the residue. The organic layer was separated and the aqueous layer was extracted with ethyl acetate. The extract was washed with $1 \mathrm{~N} \mathrm{HCl}$, then with sodium carbonate solution, again with water, and finally dried over anhydrous sodium sulfate. The solvent was evaporated under reduced pressure to give the crystalline solid.

\section{Reduction of ketophosphonates (1a-f, 2a-c) with $\mathrm{NaBH}_{4}$-TA by Method b}

To a suspension of sodium borohydride $(0.36 \mathrm{~g}, 10 \mathrm{mmol})$ in $35 \mathrm{ml}$ of THF was added $(R, R)$ (+)-tartaric acid $(1.5 \mathrm{~g}, 10 \mathrm{mmol})$, then the reaction mixture was refluxed for $4 \mathrm{~h}$. After that a solution of ketophosphonate $(2.5 \mathrm{mmol})$ in $10 \mathrm{ml}$ of the $\mathrm{THF}$ was added at $-30^{\circ} \mathrm{C}$ and the reaction mixture was stirred at this temperature for $24 \mathrm{~h}$. Then to the reaction mixture was added $15 \mathrm{ml}$ of ethyl acetate and $35 \mathrm{ml}$ of $1 \mathrm{~N}$ hydrochloric acid dropwise. The organic layer was separated, the aqueous phase was saturated with $\mathrm{NaCl}$ and extracted two times with ethyl acetate. The organic extracts were washed with a saturated solution of $\mathrm{Na}_{2} \mathrm{CO}_{3}$ and dried with $\mathrm{Na}_{2} \mathrm{SO}_{4}$. The solvent was removed under vacuum, the residue was crystallized from acetonitrile.

Di(1R,2S,5R)-menthyl (S)-hydroxy(phenyl)methylphosphonate (S)-(3a). (Method b) Yield: $80 \%$, colorless crystals, mp. $112-113^{\circ} \mathrm{C}$. $[\alpha]_{D}{ }^{20}-87.6\left(c 1.3, \mathrm{CHCl}_{3}\right) .{ }^{1} \mathrm{H} \mathrm{NMR}\left(\mathrm{C}_{6} \mathrm{D}_{6}\right): \delta_{\mathrm{H}} 1.01$ $\left(3 \mathrm{H}, \mathrm{d}^{3} \mathrm{~J}_{\mathrm{HH}}=6.9, \mathrm{CH}_{3}\right), 1.04\left(3 \mathrm{H}, \mathrm{d},{ }^{3} J_{\mathrm{HH}}=6.9, \mathrm{CH}_{3}\right), 1.08\left(3 \mathrm{H}, \mathrm{d},{ }^{3} J_{\mathrm{HH}}=6.9 \mathrm{~Hz}, \mathrm{CH}_{3}\right), 1.18(3 \mathrm{H}$, $\left.\mathrm{d},{ }^{3} J_{\mathrm{HH}}=6.9 \mathrm{~Hz}, \mathrm{CH}_{3}\right), 1.20\left(3 \mathrm{H}, \mathrm{d},{ }^{3} J_{\mathrm{HH}} 6.9 \mathrm{~Hz}, \mathrm{CH}_{3}\right), 1.21\left(3 \mathrm{H}, \mathrm{d},{ }^{3} J_{\mathrm{HH}}=6.9 \mathrm{~Hz}, \mathrm{CH}_{3}\right), 1.40-$ $2.6\left(14 \mathrm{H}, \mathrm{m}, \mathrm{CH}_{3}\right.$ and $\left.\mathrm{CH}\right), 2.00\left[1 \mathrm{H}, \mathrm{m}, \mathrm{CH}\left(\mathrm{CH}_{3}\right)_{2}\right], 2.4\left[1 \mathrm{H}, \mathrm{m}, \mathrm{CH}\left(\mathrm{CH}_{3}\right)_{2}\right], 4.49(2 \mathrm{H}, \mathrm{m}$, $\mathrm{OCH}), 5.2\left(1 \mathrm{H}, \mathrm{d}, J_{\mathrm{HP}}=10.5 \mathrm{~Hz}, \mathrm{CHP}\right), 5.10(1 \mathrm{H}, \mathrm{br}, \mathrm{OH}), 7.48(3 \mathrm{H}, \mathrm{m}, \mathrm{ArH}), 7.8(2 \mathrm{H}, \mathrm{m}, \operatorname{ArH})$. $\mathrm{dC}(100.6 \mathrm{MHz}, \mathrm{CDCl} 3) 127.98$ (d, $J=2.5 \mathrm{~Hz}), 127.8$ (d, $J=2.5 \mathrm{~Hz}), 127.4$ (d, J= 9.6 Hz), 71.8 (d, $J=160 \mathrm{~Hz}), 48.4$ (d, $J=14 \mathrm{~Hz}), 48.3$ (d, $J=13.2 \mathrm{~Hz}$ ), 45.66, 42.53, 34.01, 31.5, 25.33, 22.7, 21.98, 21.13, 21.03, 15.73, 15.61; ${ }^{31} \mathrm{P}$ NMR $\left(\mathrm{CDCl}_{3}\right)$, $\delta: 22.3$. Mass-spectrum $(70 \mathrm{eV}): \mathrm{m} / \mathrm{z} 464$ $\left(\mathrm{M}^{+}\right)$. Anal. Calcd for $\mathrm{C}_{27} \mathrm{H}_{45} \mathrm{O}_{4} \mathrm{P}: \mathrm{C}, 69.80 ; \mathrm{H}, 9.76 ; \mathrm{P}, 6.67$. Found C, 69.53; H, 9.80; P, 6.38.

$\operatorname{Di}(1 R, 2 S, 5 R)$-menthyl $(R)$-hydroxy(phenyl)methylphosphonate $(R)-(3 a)$. (Method a) Yield: $50 \%$; colorless crystals; mp $139{ }^{\circ} \mathrm{C} ;[\alpha]_{\mathrm{D}}{ }^{20}-70$ (c 1, toluene). ${ }^{1} \mathrm{H}$ NMR $\left(\mathrm{CDCl}_{3}\right): \delta_{\mathrm{H}} 0.7-1.0(\mathrm{~m}$, $\left.\mathrm{CH}_{3}\right) ; 1.1-1.23\left(\mathrm{~m}, \mathrm{CH}_{2}+\mathrm{CH}\right) ; 3.7(\mathrm{br}, \mathrm{OH}) ; 4.2\left(\mathrm{dt}, \mathrm{OCH}, J_{\mathrm{HH}}=2.3 \mathrm{~Hz}, J_{\mathrm{HH}}=4.1\right) ; 4.92(\mathrm{~d}$, $\left.\mathrm{CHP}, J_{\mathrm{HP}}=11 \mathrm{~Hz}\right) ; 7.2-7.3\left(\mathrm{~m}, \mathrm{C}_{6} \mathrm{H}_{5}\right) ; 7.3-7.5\left(\mathrm{~m}, \mathrm{C}_{6} \mathrm{H}_{5}\right) .{ }^{13} \mathrm{C} \mathrm{NMR}\left(\mathrm{CDCl}_{3}\right): \delta_{\mathrm{C}} 127.99(\mathrm{~d}, J=$ $2.5 \mathrm{~Hz}) ; 127.8\left(\mathrm{~d}, J_{\mathrm{CP}}=2.5 \mathrm{~Hz}\right) ; 127.3\left(\mathrm{~d}, J_{\mathrm{CP}}=9.6 \mathrm{~Hz}, \mathrm{C}_{6} \mathrm{H}_{5},\right) ; 71.6\left(\mathrm{~d}, J_{\mathrm{CP}}=60 \mathrm{~Hz}, \mathrm{PC}\right) ; 48.6(\mathrm{~d}$, 
$\left.{ }^{\mathrm{a}} J_{\mathrm{CP}}=14 \mathrm{~Hz}, \mathrm{CHO}\right) ; 48.5\left(\mathrm{~d}, J_{\mathrm{CP}}=13.2 \mathrm{~Hz}, \mathrm{CHO}^{\mathrm{b}}\right) ; 45.66, \mathrm{~s} ; 42.53, \mathrm{~s} ; 34, \mathrm{~s} ; 31.5, \mathrm{~s} ; 25.31, \mathrm{~s} ; 22.7$, s; 21.97,s; 21.13,s; 21.03,s; 15,74, 15.60 (diastereotopic menthyl groups). ${ }^{31} \mathrm{P}$ NMR $\left(\mathrm{CDCl}_{3}\right), \delta_{\mathrm{P}}=$ 23.71. (Method b) Yield 95\%, mp $139^{\circ} \mathrm{C},[\alpha]_{\mathrm{D}}{ }^{20}-70\left(c\right.$ 1.07, $\left.\mathrm{CHCl}_{3}\right)$. ${ }^{1} \mathrm{H}$ NMR $\left(\mathrm{CDCl}_{3}\right): \delta_{\mathrm{H}}$ 0.7-1.0 $\left(18 \mathrm{H}, \mathrm{m} \mathrm{CH}_{3}\right), 1.1-1.23\left(18 \mathrm{H}, \mathrm{m} \mathrm{CH}_{2}+\mathrm{CH}\right), 3.7(1 \mathrm{H}, \mathrm{br}, \mathrm{OH}), 4.2\left(2 \mathrm{H}, \mathrm{dt}, \mathrm{OCH}, J_{\mathrm{HH}}=\right.$ $\left.2.3 \mathrm{~Hz}, J_{\mathrm{HH}}=4.1 \mathrm{~Hz}\right), 4.92\left(1 \mathrm{H}, \mathrm{d}, J_{\mathrm{HP}}=11 \mathrm{~Hz}, \mathrm{CHP}\right), 7.2-7.3\left(3 \mathrm{H}, \mathrm{m}, \mathrm{C}_{6} \mathrm{H}_{5}\right), 7.3-7.5(2 \mathrm{H}, \mathrm{m}$ $\left.\mathrm{C}_{6} \mathrm{H}_{5}\right) .{ }^{13} \mathrm{C}$ NMR $\left(\mathrm{CDCl}_{3}\right): \delta_{\mathrm{C}} 127.99(\mathrm{~d}, J=2.5 \mathrm{~Hz}), 127.8\left(\mathrm{~d}, J_{\mathrm{CP}}=2.5\right), 127.3\left(\mathrm{~d}, \mathrm{C}_{6} \mathrm{H}_{5}, J_{\mathrm{CP}}=9.6\right.$ $\mathrm{Hz}), 71.6\left(\mathrm{~d}, \mathrm{PC}, J_{\mathrm{CP}}=160 \mathrm{~Hz}\right), 48.6\left(\mathrm{~d}, J_{\mathrm{CP}}=14 \mathrm{~Hz}, \mathrm{CHO}^{\mathrm{a}}\right), 48.5\left(\mathrm{~d}, J_{\mathrm{CP}}=13.2 \mathrm{~Hz}, \mathrm{CHO}^{\mathrm{b}}\right)$, $45.66, \mathrm{~s} ; 42.53, \mathrm{~s} ; 34, \mathrm{~s} ; 31.5, \mathrm{~s} ; 25.31, \mathrm{~s} ; 22.7, \mathrm{~s} ; 21.97, \mathrm{~s} ; 21.13, \mathrm{~s} ; 21.03, \mathrm{~s} ; 15,74,15.60$. Massspectrum $(70 \mathrm{eV}): \mathrm{m} / \mathrm{z} 464\left(\mathrm{M}^{+}\right)$.

Di(1R,2S,5R)-menthyl (S)-hydroxy(2-fluorophenyl)methylphosphonate $(S)$-(3b). (Method a) Yield: $97 \%$; colorless crystals; mp 137.5-138.5 ${ }^{\circ} \mathrm{C}$. $[\alpha]_{\mathrm{D}}{ }^{20}-83.7$ (c 1.3, $\left.\mathrm{CHCl}_{3}\right) .{ }^{1} \mathrm{H}$ NMR $\left(\mathrm{C}_{6} \mathrm{D}_{6}\right)$ : $\delta_{\mathrm{H}} 0.71\left(3 \mathrm{H}, \mathrm{d},{ }^{3} J_{\mathrm{HH}}=6.9, \mathrm{CH}_{3}\right) ; 0.76\left(3 \mathrm{H}, \mathrm{d},{ }^{3} J_{\mathrm{HH}}=6.9, \mathrm{CH}_{3}\right) ; 0.86\left(3 \mathrm{H}, \mathrm{d},{ }^{3} J_{\mathrm{HH}}=6.9 \mathrm{~Hz}, \mathrm{CH}_{3}\right)$; $0.91\left(\mathrm{~d},{ }^{3} J_{\mathrm{HH}}=6.9 \mathrm{~Hz}, \mathrm{CH}_{3}\right) ; 1.00-2.25\left(\mathrm{~m}, \mathrm{CH}_{3}\right.$ and $\left.\mathrm{CH}\right) ; 1.74\left[\mathrm{~m}, \mathrm{CH}\left(\mathrm{CH}_{3}\right)_{2}\right] ; 2.0[\mathrm{~m}$, $\left.\mathrm{CH}\left(\mathrm{CH}_{3}\right)_{2}\right] ; 4.04\left(1 \mathrm{H}, \mathrm{d}, J_{\mathrm{HH}}=22.5 \mathrm{~Hz}, \mathrm{CHP}\right) ; 4.2(1 \mathrm{H}, \mathrm{m}, \mathrm{OCH}), 5.18(1 \mathrm{H}, \mathrm{br}, \mathrm{OH}) ; 6.9(2 \mathrm{H}, \mathrm{t}$, $\left.J_{\mathrm{HH}}=8.2 \mathrm{~Hz}, \mathrm{C}_{6} \mathrm{H}_{4}\right) ; 7.45\left(2 \mathrm{H}, \mathrm{m}, \mathrm{C}_{6} \mathrm{H}_{4}\right) .{ }^{31} \mathrm{P}$ NMR $\left(\mathrm{CDCl}_{3}\right), \delta_{\mathrm{P}}=19.8$. (Method b). Yield 97\%, mp 137.5-138.5 ${ }^{\circ} \mathrm{C},[\alpha]_{D}{ }^{20}-83.7\left(c 1.3, \mathrm{CHCl}_{3}\right) .{ }^{1} \mathrm{H} \mathrm{NMR}\left(\mathrm{C}_{6} \mathrm{D}_{6}\right): \delta_{\mathrm{H}} 0.71\left(3 \mathrm{H}, \mathrm{d},{ }^{3} \mathrm{~J}_{\mathrm{HH}}=6.9 \mathrm{~Hz}\right.$, $\left.\mathrm{CH}_{3}\right), 0.76 \mathrm{~d}\left(6 \mathrm{H}, \mathrm{CH}_{3},{ }^{3} J_{\mathrm{HH}}=6.9 \mathrm{~Hz}\right), 0.86 \mathrm{~d}\left(6 \mathrm{H}, \mathrm{CH}_{3},{ }^{3} \mathrm{~J}_{\mathrm{HH}}=6.9 \mathrm{~Hz}\right), 0.91 \mathrm{~d}\left(3 \mathrm{H}, \mathrm{CH}_{3},{ }^{3} J_{\mathrm{HH}}=\right.$ $6.9 \mathrm{~Hz}), 1.00-2.25 \mathrm{~m}\left(14 \mathrm{H}, \mathrm{CH}_{3}\right.$ and $\left.\left.\mathrm{CH}\right), 1.74 \mathrm{~m}\left[1 \mathrm{H}, \mathrm{C} \underline{\mathrm{H}}\left(\mathrm{CH}_{3}\right)_{2}\right], 2.0 \mathrm{~m} \mathrm{[1H}, \mathrm{C} \underline{\mathrm{H}}\left(\mathrm{CH}_{3}\right)_{2}\right], 4.04$ $\mathrm{d}\left(1 \mathrm{H}, \mathrm{CHP}, J_{\mathrm{HH}}=22.5\right), 4.2 \mathrm{~m}(2 \mathrm{H}, \mathrm{OCH}), 5.18 \mathrm{br}(1 \mathrm{H}, \mathrm{OH}), 6.9 \mathrm{t}\left(3 \mathrm{H}, J_{\mathrm{HH}}=8.2 \mathrm{~Hz}, \mathrm{C}_{6} \mathrm{H}_{4}\right)$, $7.45 \mathrm{~m}\left(2 \mathrm{H}, \mathrm{C}_{6} \mathrm{H}_{4}\right) . \delta_{\mathrm{C}}\left(100.6 \mathrm{MHz}, \mathrm{CDCl}_{3}\right) 164.2,164.1,161.6,161.5,130.7,130.4,130.3$, 130.2, 125.8, 116.4, 116.1, 114.2, 114.4, 72.4, 70.8, 49.3, 49.16, 49.0, 48.3, 45.7, 42.5, 34.0, 31.5, 25.3, 22.7, 22.0, 21.1, 21.0, 15.7, 15.6; ${ }^{31} \mathrm{P}$ NMR $\left(\mathrm{CDCl}_{3}\right): \delta_{\mathrm{P}} 19.8$. Anal. Calcd for $\mathrm{C}_{27} \mathrm{H}_{44} \mathrm{FO}_{4} \mathrm{P}$ : C 67.20; H 9.19; P, 6.42. Found: C 67.00; H 9.20; P, 6.38.

$\operatorname{Di}(1 R, 2 S, 5 R)$-menthyl $(S)$-hydroxy-(2-metoxyphenyl)methylphosphonate $(S)$-(3c). (Method a) Prepared similarly to compound 3a. Yield: $74 \%$; colorless crystals; mp $116-117{ }^{\circ} \mathrm{C}$. $[\alpha]_{\mathrm{D}}{ }^{20}$ $-75.2\left(\mathrm{c} 0.66, \mathrm{CHCl}_{3}\right) .{ }^{1} \mathrm{H}$ NMR $\left(\mathrm{C}_{6} \mathrm{D}_{6}\right)$ : $\delta_{\mathrm{H}} 0.60\left(\mathrm{~d}, \mathrm{CH}_{3},{ }^{3} \mathrm{~J}_{\mathrm{HH}}=6.9 \mathrm{~Hz}\right) ; 0.52\left(\mathrm{~d}, \mathrm{CH}_{3}, 3 \mathrm{H}, J_{\mathrm{HH}}\right.$ $=6.9 \mathrm{~Hz}) ; 0.73\left(\mathrm{~d}, \mathrm{CH}_{3},{ }^{3} \mathrm{~J}_{\mathrm{HH}}=6.9\right) ; 0.79\left(\mathrm{~m}, 2 \mathrm{CH}_{3}\right) ; 0.84\left(\mathrm{~d}, \mathrm{CH}_{3},{ }^{3} J_{\mathrm{HH}}=6.9 \mathrm{~Hz}\right) ; 0.92-1.54(\mathrm{~m}$, $\mathrm{CH}_{2}$ and $\left.\mathrm{CH}\right) ; 2.14\left[\mathrm{~m}, \mathrm{CH}\left(\mathrm{CH}_{3}\right)_{2}\right] ; 2.40\left[\mathrm{~m}, \mathrm{CH}\left(\mathrm{CH}_{3}\right)_{2}\right] ; 3.59\left(\mathrm{~s}, \mathrm{OCH}_{3}\right) ; 4.17(\mathrm{~m}, \mathrm{OCH}) ; 4.03$ $(\mathrm{m}, \mathrm{OCH}) ; 4.54(\mathrm{br}, \mathrm{OH}) ; 5.24 \mathrm{~d}\left(1 \mathrm{H}, \mathrm{CHP}, J_{\mathrm{HH}}=13.2 \mathrm{~Hz}\right) ; 6.59 \mathrm{~d}\left(1 \mathrm{H}, \mathrm{ArH}, J_{\mathrm{HH}}=8.1 \mathrm{~Hz}\right) ; 6.80$ $\left(\mathrm{t}, 1 \mathrm{H}, \mathrm{ArH}, J_{\mathrm{HH}}=7.9 \mathrm{~Hz}\right) ; 7.04\left(\mathrm{t}, 1 \mathrm{H}, \mathrm{ArH}, J_{\mathrm{HH}}=7.9 \mathrm{~Hz}\right) ; 7.60\left(\mathrm{~d}, \mathrm{ArH}, J_{\mathrm{HH}}=7.5 \mathrm{~Hz}\right) .{ }^{31} \mathrm{P} \mathrm{NMR}$ $\left(\mathrm{CDCl}_{3}\right), \delta_{\mathrm{P}}=21.13$. (Method b) Yield 74\%, mp 116-117 ${ }^{\circ} \mathrm{C},[\alpha]_{D}{ }^{20}-75.2\left(c 0.66, \mathrm{CHCl}_{3}\right) .{ }^{1} \mathrm{H}$ $\operatorname{NMR}\left(\mathrm{C}_{6} \mathrm{D}_{6}\right): \delta_{\mathrm{H}} 0.60 \mathrm{~d}\left(3 \mathrm{H},{ }^{3} J_{\mathrm{HH}}=6.9 \mathrm{~Hz}, \mathrm{CH}_{3}\right), 0.52\left(3 \mathrm{H}, \mathrm{d},{ }^{3} J_{\mathrm{HH}}=6.9 \mathrm{~Hz}, \mathrm{CH}_{3}\right), 0.73(3 \mathrm{H}, \mathrm{d}$, $\left.{ }^{3} J_{\mathrm{HH}}=6.9 \mathrm{~Hz}, \mathrm{CH}_{3}\right), 0.79\left(6 \mathrm{H}, \mathrm{m}, \mathrm{CH}_{3}\right), 0.84\left(3 \mathrm{H}, \mathrm{d},{ }^{3} \mathrm{~J}_{\mathrm{HH}}=6.9 \mathrm{~Hz}, \mathrm{CH}_{3}\right), 0.92-1.54(14 \mathrm{H}, \mathrm{m}$, $\mathrm{CH}_{2}$ and $\left.\mathrm{CH}\right), 2.14\left[1 \mathrm{H}, \mathrm{m}, \mathrm{C} \underline{\mathrm{H}}\left(\mathrm{CH}_{3}\right)_{2}\right], 2.40\left[1 \mathrm{H}, \mathrm{m}, \mathrm{C} \underline{\mathrm{H}}\left(\mathrm{CH}_{3}\right)_{2}\right], 3.59\left(3 \mathrm{H}, \mathrm{OCH}_{3}\right), 4.17(1 \mathrm{H}, \mathrm{m}$, $\mathrm{OCH}), 4.03(1 \mathrm{H}, \mathrm{m}, \mathrm{OCH}), 4.54(1 \mathrm{H}, \mathrm{br}, \mathrm{OH}), 5.24\left(1 \mathrm{H}, \mathrm{d}, J_{\mathrm{HH}}=13.2 \mathrm{~Hz}, \mathrm{CHP}\right), 6.59(1 \mathrm{H}, \mathrm{d}$, $\left.J_{\mathrm{HH}}=8.1 \mathrm{~Hz}, \mathrm{ArH}\right), 6.80\left(1 \mathrm{H}, \mathrm{t}, J_{\mathrm{HH}}=7.9 \mathrm{~Hz}, \mathrm{ArH}\right), 7.04\left(1 \mathrm{H}, \mathrm{t}, J_{\mathrm{HH}}=7.9 \mathrm{~Hz}, \mathrm{ArH}\right), 7.60(1 \mathrm{H}, \mathrm{d}$, $\left.J_{\mathrm{HH}} 7.5 \mathrm{~Hz}, \mathrm{ArH}\right) .{ }^{13} \mathrm{C} \mathrm{NMR}\left(\mathrm{CDCl}_{3}\right), \delta_{\mathrm{C}} 157.10(\mathrm{~d}, J=6.5 \mathrm{~Hz}), 129.00(\mathrm{~d}, J=2.8 \mathrm{~Hz}), 128.8(\mathrm{~d}$, $\left.J_{\mathrm{CP}}=2.8 \mathrm{~Hz}\right), 125.3\left(\mathrm{~d}, J_{\mathrm{CP}}=5.5 \mathrm{~Hz}\right), 120.6\left(\mathrm{~d}, J_{\mathrm{CP}}=2.0 \mathrm{~Hz}\right), 110.5128 .8\left(\mathrm{~d}, J_{\mathrm{CP}}=2.0 \mathrm{~Hz}, \mathrm{C}_{6} \mathrm{H}_{5}\right)$, $66.6\left(\mathrm{~d}, \mathrm{PC}, J_{\mathrm{CP}}=161 \mathrm{~Hz}\right), 55\left(\mathrm{~s}, \mathrm{CH}_{3} \mathrm{O}\right), 48.8\left(\mathrm{~d}, \mathrm{CHO},{ }^{\mathrm{a}} J_{\mathrm{CP}}=35 \mathrm{~Hz}\right), 48.5\left(\mathrm{~d}, \mathrm{CHO}^{\mathrm{b}}, J_{\mathrm{CP}}=34\right.$ $\mathrm{Hz}), 43.8, \mathrm{~s} ; 34.09$, s; 33.9, s; 31.5, s; 25.24, s; 22.7, s; 21.97, s; 21.87, s; 21.21, s; 21.05; 15,72, 
15.62. ${ }^{31} \mathrm{P}$ NMR $\left(\mathrm{CDCl}_{3}\right), \delta \mathrm{P}$ 20.98. Anal. Calcd for $\mathrm{C}_{28} \mathrm{H}_{47} \mathrm{O}_{5} \mathrm{P}: \mathrm{C}, 67.99 ; \mathrm{H}, 9.58 ; \mathrm{P}, 6.26$. Found: C, 68.16; H, 9.50; P, 6.27.

$\operatorname{Di}(1 R, 2 S, 5 R)$-menthyl (S)-hydroxy(isopropyl)methylphosphonate (3d). (Method b) Yield: $97.6 \%$, colorless crystals, mp $71^{\circ} \mathrm{C}(\mathrm{MeCN}),[\alpha]_{D}{ }^{20}-82.8\left(\right.$ c $\left.2.2, \mathrm{CHCl}_{3}\right) .{ }^{1} \mathrm{H} \mathrm{NMR}\left(\mathrm{C}_{6} \mathrm{D}_{6}\right): \delta_{\mathrm{H}}$ $0.73-0.84\left(18 \mathrm{H}, \mathrm{m}, \mathrm{CH}_{3}\right), 0.87-2.3\left(18 \mathrm{H}, \mathrm{m}, \mathrm{CH}_{2}\right.$ and $\left.\mathrm{CH}\right), 0.95\left(3 \mathrm{H}, \mathrm{d}, J_{\mathrm{HH}}=6.3 \mathrm{~Hz}\right.$, $\left.\mathrm{CH}\left(\mathrm{CH}_{3}\right)_{2}\right), 0.97\left(3 \mathrm{H}, \mathrm{d}, \mathrm{CH}\left(\mathrm{CH}_{3}\right)_{2} J_{\mathrm{HH}}=6.3 \mathrm{~Hz}\right), 1.94\left[1 \mathrm{H}, \mathrm{m}, \mathrm{C} \underline{\mathrm{H}}\left(\mathrm{CH}_{3}\right)_{2}\right], 3.33(1 \mathrm{H}, \mathrm{m}$, $\mathrm{C} \underline{\mathrm{HOH}}), 4.09$ (2H, m, OCH). ${ }^{31} \mathrm{P}$ NMR $\left(\mathrm{CDCl}_{3}\right), \delta_{\mathrm{P}}$ 24.04. Anal. Calcd for $\mathrm{C}_{24} \mathrm{H}_{47} \mathrm{O}{ }_{4} \mathrm{P}: \mathrm{C}, 66.94$; H, 11.0; P, 7.19. Found: C, 66.90; H, 10.93; P, 7.18.

Di(1R,2S,5R)-menthyl (S)-hydroxy(piperonyl)methylphosphonate (3e). (Method b) Yield $70 \%$, colorless crystals, mp $96^{\circ} \mathrm{C}(\mathrm{MeCN}),[\alpha]_{D}{ }^{20}-74\left(c 1, \mathrm{CHCl}_{3}\right) .{ }^{1} \mathrm{H} \mathrm{NMR}\left(\mathrm{C}_{6} \mathrm{D}_{6}\right): \delta_{\mathrm{H}} 0.62$ $\left(3 \mathrm{H}, \mathrm{d}, J_{\mathrm{HH}}=6.9 \mathrm{~Hz}, \mathrm{CH}_{3}\right), 0.66\left(3 \mathrm{H}, \mathrm{d}, J_{\mathrm{HH}}=6.9 \mathrm{~Hz}, \mathrm{CH}_{3}\right), 0.67\left(3 \mathrm{H}, \mathrm{d}, J_{\mathrm{HH}}=6.9 \mathrm{~Hz}, \mathrm{CH}_{3}\right)$, $0.76\left(3 \mathrm{H}, \mathrm{d}, J_{\mathrm{HH}}=6.9 \mathrm{~Hz}, \mathrm{CH}_{3}\right), 0.77\left(3 \mathrm{H}, \mathrm{d}, J_{\mathrm{HH}}=6.9 \mathrm{~Hz}, \mathrm{CH}_{3}\right), 0.81\left(3 \mathrm{H}, \mathrm{d}, J_{\mathrm{HH}}=6.9 \mathrm{~Hz}\right.$, $\left.\mathrm{CH}_{3}\right), 0.9-2.27\left(16 \mathrm{H}, \mathrm{m}, \mathrm{CH}_{2}\right.$ and $\left.\mathrm{CH}\right), 1.48\left[1 \mathrm{H}, \mathrm{m}, \mathrm{C} \underline{\mathrm{H}}\left(\mathrm{CH}_{3}\right)_{2}\right], 1.94$ [1H, m, $\left.\underline{\mathrm{C}}\left(\mathrm{CH}_{3}\right)_{2}\right], 4.09$ $(2 \mathrm{H}, \mathrm{m}, \mathrm{OCH}), 4.7\left(1 \mathrm{H}, \mathrm{d}, J_{\mathrm{HP}}=10.5, \mathrm{CHP}\right), 5.38(1 \mathrm{H}, \mathrm{br}, \mathrm{OH}), 5.65\left(2 \mathrm{H}, \mathrm{s}, \mathrm{CH}_{2} \mathrm{O}_{2}\right), 6.57(1 \mathrm{H}$, $\left.\mathrm{d}, J_{\mathrm{HH}}=7.9 \mathrm{~Hz}, \mathrm{C}_{6} \mathrm{H}_{3}\right), 6.85\left(1 \mathrm{H}, \mathrm{d}, J_{\mathrm{HH}}=7.9 \mathrm{~Hz}, \mathrm{C}_{6} \mathrm{H}_{3}\right), 6.98\left(1 \mathrm{H}, \mathrm{s}, \mathrm{C}_{6} \mathrm{H}_{3}\right) .{ }^{31} \mathrm{P} \mathrm{NMR}\left(\mathrm{CDCl}_{3}\right), \delta_{\mathrm{P}}$ 19.8. Anal. Calcd for $\mathrm{C}_{28} \mathrm{H}_{45} \mathrm{O}_{6} \mathrm{P}: 66.12 ; \mathrm{H}, 8.92 ; \mathrm{P}, 6.09 \%$. Found: $\mathrm{C}, 66.17 ; \mathrm{H}, 8.83 ; \mathrm{P}, 6.14$.

Diethyl (S)-hydroxy(phenyl)methylphosphonate $(\boldsymbol{S})$-(3f). (Method b) Yield: $95 \%$, colorless solid, mp $74-76^{\circ} \mathrm{C} .[\alpha]_{D}{ }^{20}-15.4\left(c\right.$ 2.6, $\left.\mathrm{CHCl}_{3}\right) .{ }^{1} \mathrm{H}$ NMR $\left(\mathrm{C}_{6} \mathrm{D}_{6}\right): \delta_{\mathrm{H}} 1.21\left(3 \mathrm{H}, \mathrm{t}^{3} J_{\mathrm{HH}}=7.1\right.$, $\left.\mathrm{CH}_{3},\right), 1.26\left(3 \mathrm{H}, \mathrm{t},{ }^{3} \mathrm{~J}_{\mathrm{HH}}=7.1, \mathrm{CH}_{3}\right), 3.8(1 \mathrm{H}, \mathrm{br}, \mathrm{OH}), 3.90-4.13\left(4 \mathrm{H}, \mathrm{m}, \mathrm{CH}_{2}\right), 5.01\left(1 \mathrm{H}, \mathrm{d}, J_{\mathrm{PH}}\right.$ $=10.9 \mathrm{~Hz}, \mathrm{CH}), 7.3-7.38(3 \mathrm{H}, \mathrm{m}, \mathrm{ArH}), 7.49(2 \mathrm{H}, \mathrm{d}, \mathrm{ArH}) .{ }^{31} \mathrm{P} \mathrm{NMR}\left(\mathrm{CDCl}_{3}\right), \delta_{\mathrm{P}} 22.00$ that corresponds to 29

Diethyl-(R)-hydroxy(phenyl)methylphosphonate $(\boldsymbol{R})$-(3f). (Method b) Yield 94\%, mp 74$76^{\circ} \mathrm{C}$. $[\alpha]_{D}{ }^{20}+28.3\left(c 2.1, \mathrm{CHCl}_{3}\right)$, that corresponds to ${ }^{31}$.

Diethyl (S)-(-)-2-hydroxy-3-chloropropylphosphonate (S)-(4a). (Method b) Yield: 85\%. $[\alpha]_{D}{ }^{20}-12.42\left(c 3.22, \mathrm{CHCl}_{3}\right) .{ }^{1} \mathrm{H}$ NMR $\left(\mathrm{C}_{6} \mathrm{D}_{6}\right): \delta_{\mathrm{H}} 1.18\left(6 \mathrm{H} \mathrm{t},{ }^{3} J_{\mathrm{HH}}=7.2 \mathrm{~Hz}, \mathrm{CH}_{3} \mathrm{CH}_{2}\right), 1.79 \mathrm{ddd}$ $\left(1 \mathrm{H},{ }^{2} J_{\mathrm{HP}}=17.1 \mathrm{~Hz},{ }^{2} J_{\mathrm{HH}}=15.3 \mathrm{~Hz},{ }^{3} J_{\mathrm{HH}}=9.4 \mathrm{~Hz}, \mathrm{PC}{ }^{\mathrm{a}} \mathrm{H}\right), 2.02\left(1 \mathrm{H}\right.$, ddd, ${ }^{2} J_{\mathrm{HP}}=18.9 \mathrm{~Hz},{ }^{2} J_{\mathrm{HH}}$ $\left.=15.3 \mathrm{~Hz},{ }^{3} J_{\mathrm{HH}}=3.4 \mathrm{~Hz}, \mathrm{PC}^{\mathrm{b}} \mathrm{H}\right), 3.26\left(1 \mathrm{H}, \mathrm{dd},{ }^{2} J_{\mathrm{HH}}=10.8 \mathrm{~Hz},{ }^{3} J_{\mathrm{HH}}=7.2 \mathrm{~Hz}, \mathrm{C}^{\mathrm{a}} \mathrm{HCl}\right), 3.44(1 \mathrm{H}$, $\left.\mathrm{ddd},{ }^{2} J_{\mathrm{HH}}=10.8 \mathrm{~Hz},{ }^{3} J_{\mathrm{HH}}=4.4 \mathrm{~Hz},{ }^{4} J_{\mathrm{PH}}=3.4 \mathrm{~Hz}, \mathrm{C}^{\mathrm{b}} \mathrm{HCl}\right), 3.96\left(5 \mathrm{H}, \mathrm{m} \mathrm{CH}_{2} \mathrm{O}+\mathrm{C} \underline{\mathrm{HOH}}\right), 4.62(1 \mathrm{H}$, $\mathrm{m} \mathrm{OH}) .{ }^{31} \mathrm{P}$ NMR $\left(\mathrm{CDCl}_{3}\right), \delta_{\mathrm{P}}$ 29.4. Anal. Calcd for $\mathrm{C}_{7} \mathrm{H}_{16} \mathrm{ClO}_{4} \mathrm{P}: \mathrm{C}, 36.46 ; \mathrm{H}, 6.99 ; \mathrm{P}, 13.43$. Found: C, 36.2; H, 6.4; P, 13.50 .

Diethyl $(\boldsymbol{R})-(+)-2-h y d r o x y-3-c h l o r o p r o p y l p h o s p h o n a t e ~(R)-(4 a)$. (Method b) Yield: $85 \%$. $\left.[\alpha]_{D}{ }^{20}+12.4(c) 3.2, \mathrm{CHCl}_{3}\right) .{ }^{1} \mathrm{H}$ NMR $\left(\mathrm{C}_{6} \mathrm{D}_{6}\right): \delta_{\mathrm{H}} 1.18\left(6 \mathrm{H}, \mathrm{t},{ }^{3} J_{\mathrm{HH}} 7.2 \mathrm{~Hz}, \mathrm{CH}_{3} \mathrm{CH}_{2}\right), 1.79(1 \mathrm{H}$, $\left.\mathrm{ddd},{ }^{2} J_{\mathrm{HP}}=17.1 \mathrm{~Hz},{ }^{2} J_{\mathrm{HH}}=15.3 \mathrm{~Hz},{ }^{3} J_{\mathrm{HH}}=9.4 \mathrm{~Hz}, \mathrm{PC}{ }^{\mathrm{a}} \mathrm{H}\right), 2.02\left(1 \mathrm{H}, \mathrm{ddd},{ }^{2} J_{\mathrm{HP}}=18.9 \mathrm{~Hz},{ }^{2} J_{\mathrm{HH}}\right.$ $\left.=15.3 \mathrm{~Hz},{ }^{3} J_{\mathrm{HH}}=3.4 \mathrm{~Hz}, \mathrm{PC}^{\mathrm{b}} \mathrm{H}\right), 3.26\left(1 \mathrm{H}, \mathrm{dd},{ }^{2} J_{\mathrm{HH}}=10.8 \mathrm{~Hz},{ }^{3} J_{\mathrm{HH}}=7.2 \mathrm{~Hz}, \mathrm{C}^{\mathrm{a}} \mathrm{HCl}\right), 3.44(1 \mathrm{H}$, $\left.\mathrm{ddd},{ }^{2} J_{\mathrm{HH}}=10.8 \mathrm{~Hz},{ }^{3} J_{\mathrm{HH}}=4.4 \mathrm{~Hz},{ }^{4} J_{\mathrm{PH}}=3.4 \mathrm{~Hz}, \mathrm{C}^{\mathrm{b}} \mathrm{HCl}\right), 3.96\left(5 \mathrm{H}, \mathrm{m}, \mathrm{CH}_{2} \mathrm{O}+\mathrm{C} \underline{\mathrm{HOH}}\right), 4.62(1 \mathrm{H}$, $\mathrm{m}, \mathrm{OH}) .{ }^{31} \mathrm{P}$ NMR $\left(\mathrm{CDCl}_{3}\right), \delta_{\mathrm{P}}$ 29.4. Anal. Calcd for $\mathrm{C}_{7} \mathrm{H}_{16} \mathrm{ClO}_{4} \mathrm{P}: \mathrm{C}, 36.46 ; \mathrm{H}, 6.99 ; \mathrm{P}, 13.43$. Found: C, 36.27; H, 6.54; P, 13.51.

Di(1R,2S,5R)-menthyl (S)-(-)-2-hydroxy-3-chloropropylphosphonate (S)-(4b). (Method b) Yield 95\%, colorless solid. Mp $86.2{ }^{\circ} \mathrm{C} .[\alpha]_{D}{ }^{20}-97.16$ (c 3, $\left.\mathrm{CHCl}_{3}\right) .{ }^{1} \mathrm{H} \mathrm{NMR}\left(\mathrm{C}_{6} \mathrm{D}_{6}\right): \delta_{\mathrm{H}} 0.71$ $\left(3 \mathrm{H}, \mathrm{d},{ }^{3} J_{\mathrm{HH}}=6.9 \mathrm{~Hz}, \mathrm{CH}_{3}\right), 0.76\left(3 \mathrm{H}, \mathrm{d},{ }^{3} J_{\mathrm{HH}}=6.9 \mathrm{~Hz}, \mathrm{CH}_{3}\right), 0.81-0.84\left(12 \mathrm{H}, \mathrm{m}, \mathrm{CH}_{3}\right), 0.88-$ 
$2.18\left(17 \mathrm{H}, \mathrm{m}, \mathrm{CH}_{2}+\mathrm{CH}\right), 1.53\left[1 \mathrm{H}, \mathrm{m}, \mathrm{C} \underline{\mathrm{H}}\left(\mathrm{CH}_{3}\right)_{2}\right], 1.73\left(1 \mathrm{H}, \mathrm{m}, \mathrm{CH}^{\mathrm{a}} \mathrm{P}\right), 1.97\left(1 \mathrm{H}, \mathrm{m}, \mathrm{CH}^{\mathrm{b}} \mathrm{P}\right)$, $1.96\left[1 \mathrm{H}, \mathrm{m}, \mathrm{C} \underline{\mathrm{H}}\left(\mathrm{CH}_{3}\right)_{2}\right], 3.29\left(1 \mathrm{H}, \mathrm{dd},{ }^{2} J_{\mathrm{HH}}=10.8 \mathrm{~Hz},{ }^{3} J_{\mathrm{HH}}=6.7 \mathrm{~Hz}, \mathrm{CH}^{\mathrm{a}} \mathrm{Cl}\right), 3.43(1 \mathrm{H}$, ddd, $\left.{ }^{2} J_{\mathrm{HH}}=10.8 \mathrm{~Hz},{ }^{3} J_{\mathrm{HH}}=4.7 \mathrm{~Hz},{ }^{4} J_{\mathrm{PH}}=2.8 \mathrm{~Hz}, \mathrm{CH}^{\mathrm{b} C l}\right), 3.9-4.10(2 \mathrm{H}, \mathrm{m}, \mathrm{OCH}), 4.15(1 \mathrm{H}, \mathrm{m}$, C바), $4.44(1 \mathrm{H}, \mathrm{br}, \mathrm{OH}) . \delta_{\mathrm{C}}\left(100.6 \mathrm{MHz}, \mathrm{CDCl}_{3}\right) 78.37(\mathrm{~d}, J=7.5 \mathrm{~Hz}), 78.34(\mathrm{~d}, J=7.5 \mathrm{~Hz})$, 67.29 (d, $J=3.6 \mathrm{~Hz}), 49.36$ (d, $J=18.2 \mathrm{~Hz}), 49.08$ (d, J=6.5 Hz), 49.07 (d, J=6.5 Hz), 44.13, 43.62, 34.49, 34.49, 32.61 (d, $J=141.2 \mathrm{~Hz}), 32.01,31.98,26.12,26.00,23.41,23.40,22.25$, 22.24, 21.41, 21.34, 16.36, 16.13. ${ }^{31} \mathrm{P}$ NMR $\left(\mathrm{CDCl}_{3}\right), \delta_{\mathrm{P}} 28.81$. Anal. Calcd for $\mathrm{C}_{23} \mathrm{H}_{44} \mathrm{ClO}_{4} \mathrm{P}: \mathrm{C}$, 61.25; H, 9.83; P, 6.87. Found: C, 61.28; H, 9.86; P, 6.88.

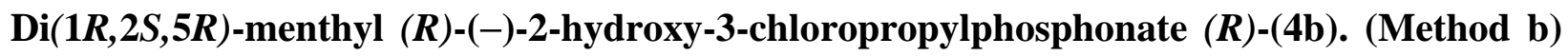
Colorless solid, mp $76.5{ }^{\circ} \mathrm{C} .[\alpha]_{D}{ }^{20}-64.3\left(c 2, \mathrm{CHCl}_{3}\right) .{ }^{1} \mathrm{H} \mathrm{NMR}\left(\mathrm{C}_{6} \mathrm{D}_{6}\right): \delta_{\mathrm{H}} 0.72\left(3 \mathrm{H}, \mathrm{d},{ }^{3} J_{\mathrm{HH}}\right.$ $\left.=6.9 \mathrm{~Hz}, \mathrm{CH}_{3}\right), 0.73\left(3 \mathrm{H}, \mathrm{d},{ }^{3} J_{\mathrm{HH}}=6.9 \mathrm{~Hz}, \mathrm{CH}_{3}\right), 0.81-0.84\left(12 \mathrm{H}, \mathrm{m}, \mathrm{CH}_{3}\right), 0.88-2.18(17 \mathrm{H}, \mathrm{m}$, $\left.\mathrm{CH}_{2}+\mathrm{CH}\right), 1.53\left[1 \mathrm{H}, \mathrm{m}, \mathrm{C} \underline{\mathrm{H}}\left(\mathrm{CH}_{3}\right)_{2}\right], 1.71\left(1 \mathrm{H}, \mathrm{ddd},{ }^{2} J_{\mathrm{HP}}=15.7 \mathrm{~Hz},{ }^{2} J_{\mathrm{HH}}=15.5,{ }^{3} J_{\mathrm{HH}}=9.1 \mathrm{~Hz}\right.$, $\left.\mathrm{CH}^{\mathrm{a}} \mathrm{P}\right), 1.97\left(1 \mathrm{H}, \mathrm{m} \mathrm{CH}{ }^{\mathrm{b}} \mathrm{P}\right), 1.96\left[1 \mathrm{H}, \mathrm{m}, \mathrm{C} \underline{\mathrm{H}}\left(\mathrm{CH}_{3}\right)_{2}\right], 3.29\left(1 \mathrm{H}, \mathrm{dd},{ }^{2} J_{\mathrm{HH}}=10.8 \mathrm{~Hz},{ }^{3} J_{\mathrm{HH}}=7.4\right.$, $\left.\mathrm{CH}^{\mathrm{a} C l}\right), 3.43\left(1 \mathrm{H}, \mathrm{ddd},{ }^{2} J_{\mathrm{HH}}=10.8 \mathrm{~Hz},{ }^{3} J_{\mathrm{HH}}=4.4 \mathrm{~Hz},{ }^{4} J_{\mathrm{PH}}=3.4 \mathrm{~Hz}, \mathrm{CH}^{\mathrm{b}} \mathrm{Cl}\right), 3.9-4.05(2 \mathrm{H}, \mathrm{m}$, $\mathrm{OCH}), 3.95(1 \mathrm{H}, \mathrm{m}, \mathrm{CHOH}), 4.25(1 \mathrm{H}, \mathrm{br}, \mathrm{OH}) . \delta_{\mathrm{C}}\left(100.6 \mathrm{MHz}, \mathrm{CDCl}_{3}\right) 78.36(\mathrm{~d}, J=7.5 \mathrm{~Hz})$, 78.33 (d, $J=7.5 \mathrm{~Hz}), 67.29$ (d, $J=3.6 \mathrm{~Hz}), 49.36$ (d, $J=18.2 \mathrm{~Hz}), 49.08$ (d, $J=6.5 \mathrm{~Hz}), 49.07$ (d, $J=6.5 \mathrm{~Hz}), 44.13,43.62,34.49,34.49,32.64$ (d, $J=141.2 \mathrm{~Hz}), 32.01,31.98,26.12,26.00$, 23.43, 23.40, 22.25, 22.24, 21.41, 21.34, 16.37, 16.13. ${ }^{31} \mathrm{P} \mathrm{NMR}\left(\mathrm{CDCl}_{3}\right): \delta_{\mathrm{P}} 28.7$. Anal. Calcd for $\mathrm{C}_{23} \mathrm{H}_{44} \mathrm{ClO}_{4} \mathrm{P}: \mathrm{C}, 61.25 ; \mathrm{H}, 9.83 ; \mathrm{P}$ 6.87. Found: C, 61.28; H, 9.86; P, 6.88.

Diethyl $(R)-2-h y d r o x y-2-p h e n y l e t h y l p h o s p h o n a t e ~(R)-(4 c)$. (Method b) Yield 95\%, yellow oil; $[\alpha]_{\mathrm{D}}{ }^{20}-25\left(c 2.38, \mathrm{CHCl}_{3}\right) .{ }^{1} \mathrm{H} \mathrm{NMR}\left(\mathrm{C}_{6} \mathrm{D}_{6}\right): \delta_{\mathrm{H}} 1.10\left(3 \mathrm{H}, \mathrm{t},{ }^{3} J_{\mathrm{HH}}=6.9 \mathrm{~Hz}, \mathrm{CH}_{3}\right), 1.11(3 \mathrm{H}, \mathrm{t}$, $\left.{ }^{3} J_{\mathrm{HH}}=6.9 \mathrm{~Hz}, \mathrm{CH}_{3}\right), 1.90-2.12\left(2 \mathrm{H}, \mathrm{m}, \mathrm{CH}_{2}\right), 3.77-3.99\left(4 \mathrm{H}, \mathrm{m}, 2 \mathrm{CH}_{2}\right), 4.75(1 \mathrm{H}, \mathrm{br}, \mathrm{OH})$, 4.96-5.06 (1H, m, C브), $7.05\left(1 \mathrm{H}, \mathrm{t}, \mathrm{C}_{6} \mathrm{H}_{5}, J_{\mathrm{HH}}=7.2 \mathrm{~Hz}\right), 7.14\left(2 \mathrm{H}, \mathrm{t}, J_{\mathrm{HH}}=7.2 \mathrm{~Hz}, \mathrm{C}_{6} \mathrm{H}_{5}\right)$, $7.28\left(2 \mathrm{H}, \mathrm{d}, J_{\mathrm{HH}}=7.2 \mathrm{~Hz}, \mathrm{C}_{6} \mathrm{H}_{5}\right) .{ }^{31} \mathrm{P} \mathrm{NMR}\left(\mathrm{CDCl}_{3}\right): \delta \mathrm{P} 29.6$. Anal. Calcd for $\mathrm{C}_{12} \mathrm{H}_{19} \mathrm{O}_{4} \mathrm{P}: \mathrm{C}$, 55.81; H, 7.42; P, 11.99. Found: C, 55.86; H, 7.47; P, $11.90 .^{32}$

(S)-1-Phenyl(1-hydroxyl)methylphosphonic acid $(\mathbf{S})$-(5a). To a solution of hydroxyphosphonate 3a $(1.15 \mathrm{~g}, 2.5 \mathrm{mmol})$ in $50 \mathrm{ml}$ of dioxane was placed in a flask, and 25 $\mathrm{ml}$ of $6 \mathrm{~N}$. hydrochloric acid was added. The reaction mixture was left for 3 days at $80^{\circ} \mathrm{C}$. The course of reaction was monitored by ${ }^{31} \mathrm{P}$ NMR spectroscopy. When the reaction was completed, the solvent was evaporated, the residue was dissolved in ethanol and the excess of cyclohexylamine $(\sim 1.5 \mathrm{ml})$ was added, the dicyclohexylammonium salt was filtered off. Yield: $50 \%$, colorless solid, $\mathrm{mp} 226{ }^{\circ} \mathrm{C}$. $[\alpha]_{\mathrm{D}}{ }^{20}-14.0$ (c 1, MeOH-water $\left.1: 1\right)$ corresponds to the $(S)$ configuration of 5a. ${ }^{15,25}$

\section{(R)-1-Phenyl-1-hydroxymethylphosphonic acid $(\boldsymbol{R})-(5 \mathbf{a})$}

(Method a). A solution of hydroxymethylphosphonate 3a $(1 \mathrm{~g}, 2 \mathrm{mmol})$ in $50 \mathrm{~mL}$ of dioxane was placed in a flask and $25 \mathrm{~mL}$ of $6 \mathrm{~N}$ hydrochloric acid was added. The reaction mixture was then left for 3 days at $80{ }^{\circ} \mathrm{C}$. The hydrolysis was monitored by ${ }^{31} \mathrm{P}$ NMR spectroscopy. When the reaction was complete, the solvent was evaporated under reduced pressure, the residue was 
dissolved in ethanol, followed by the excess addition of cyclohexylamine $(\sim 1.5 \mathrm{ml})$. The precipitate of the dicyclohexylammonium salt was collected by filtration.

(Method b). In a round-bottomed flask, $\mathrm{NaI}$ (4 equiv.) and trimethylchlorosilane (4 eqiv.) were added to a solution of $\alpha$-hydroxyphosphonates $3 \mathbf{a}-\mathbf{c}$ ( 1 equiv.) in $\mathrm{CH}_{3} \mathrm{CN}$ (10 mL), and the resulting mixture was refluxed for $12 \mathrm{~h}$. The sodium chloride that was precipitated was filtered off. After removal of the solvent under reduced pressure, a solution of ethanol $(3 \mathrm{~mL})$ and $\mathrm{H}_{2} \mathrm{O}$ $(2.5 \mathrm{~mL})$ was added, and the resulting mixture was stirred at room temperature for $2 \mathrm{~h}$. The organic layer was separated and the water phase was evaporated in vacuo. Yield: 50\%; mp 226 ${ }^{\circ} \mathrm{C} .[\alpha]_{\mathrm{D}}{ }^{20}+14.0(\mathrm{c}=1,50 \%$ aqueous $\mathrm{MeOH})$ corresponding to the $(R)$-configuration of acid $(\boldsymbol{R})$ 5a. The hydroxyphosphonic acid was dissolved in ethanol, and excess cyclohexylamine was added to obtain a solid precipitate, which was purified by crystallization. $(R)-2 \alpha$-Cyclohexylammonium salt: $\mathrm{mp}>200{ }^{\circ} \mathrm{C} .[\alpha]_{\mathrm{D}}{ }^{20}+24.0\left(\mathrm{c}=1, \mathrm{CHCl}_{3}\right) .{ }^{25}$

(R)-1-(o-Methoxy)phenyl-1-hydroxymethylphosphonic Acid $(\boldsymbol{R})-(5 b)$ The preparation was as described for compound 3a. The product was purified by crystallization from hexane and acetonitrile, colorless solid. (R)-(5b)-(Cyclohexylammonium salt). Yield: $50 \% . \mathrm{mp}>200{ }^{\circ} \mathrm{C}$. $[\alpha]_{\mathrm{D}}{ }^{20}+30.0\left(\mathrm{c}=1, \mathrm{CHCl}_{3}\right) .{ }^{31} \mathrm{P} \mathrm{NMR}\left(\mathrm{CDCl}_{3}\right), \delta_{\mathrm{P}}=17.0$

(S)-2-Hydroxy-3-chloropropylphosphonic acid (S)-(6b). (a) To a solution of dimenthyl hydroxyphosphonate $\mathbf{4 b}(4.5 \mathrm{~g}, 10 \mathrm{mmol})$ in $250 \mathrm{ml}$ of dioxane was added $100 \mathrm{ml}$ of conc. hydrochloric acid. The reaction mixture was left for 3 days at $85{ }^{\circ} \mathrm{C}$. Then the solvent was removed under reduced pressure, to the residue was added $50 \mathrm{ml}$ of water and the mixture was washed with toluene $(3 \times 25 \mathrm{ml})$. The water was removed in vacuo, the residue was dissolved in ethanol and treated with activated charcoal. The solvent was evaporated under reduced pressure to give 6b as a colorless oil. Yield: $1.56 \mathrm{~g}$ ( $~ 90 \%)$. Spectroscopically pure product was used without further purification.

(b) A solution of hydroxyphosphonate $4 \mathbf{b}(2.3 \mathrm{~g}, 10 \mathrm{mmol})$ in $50 \mathrm{ml}$ of $\mathrm{CH}_{2} \mathrm{Cl}_{2}$ was treated with $10.5 \mathrm{ml}(80 \mathrm{mmol})$ of trimethylbromosilane and was left overnight. The solvent was evaporated, the residue was dissolved in $25 \mathrm{ml}$ of $60 \%$ aqueous ethanol. Then the solvent was removed under reduced pressure, to the residue was added $100 \mathrm{ml}$ of water and the mixture was washed with toluene $(3 \times 25 \mathrm{ml})$. The solvent was evaporated under reduced pressure to give $\mathbf{6 b}$ as a colorless oil. Yield: $1.7 \mathrm{~g}(\sim 98 \%)$ spectroscopically pure oil, which was used without further purification. ${ }^{1} \mathrm{H}$ NMR $\left(\mathrm{CD}_{3} \mathrm{OD}\right): \delta_{\mathrm{H}} 1.6-1.9\left(2 \mathrm{H}, \mathrm{m}, \mathrm{PCH}_{2}\right), 3.2-3.4\left(2 \mathrm{H}, \mathrm{m}, \mathrm{CH}_{2} \mathrm{Cl}\right), 4.8(1 \mathrm{H}, \mathrm{m}, \mathrm{CHO}) .{ }^{31} \mathrm{P}$ $\mathrm{NMR}\left(\mathrm{CDCl}_{3}\right): \delta_{\mathrm{P}} 25.5$. $^{29}$

$\operatorname{Di}(1 R, 2 S, 5 R)$-menthyl (2R)-(oxirane-2-yl)methylphosphonate $(9 \mathrm{~b})$. To a stirred solution of $\operatorname{di}(1 R, 2 S, 5 R)$-menthyl (2S)-3-chloro-2-hydroxypropylphosphonate $4 \mathbf{b}(4.5 \mathrm{~g}, 10 \mathrm{mmol})$ in a 10:3.5 mixture of acetonitrile-DMF $(100 \mathrm{ml})$ were added $\mathrm{K}_{2} \mathrm{CO}_{3}(3.0 \mathrm{~g})$ and $\mathrm{KI}(0.3 \mathrm{~g})$. The mixture was refluxed for $8 \mathrm{~h}$. Then the mixture was filtered off and the filtrate was evaporated under reduced pressure to give $9 \mathrm{~b}(4.05 \mathrm{~g}, 98 \%)$ as a colorless oil. $[\alpha]_{\mathrm{D}}{ }^{20}-62.4\left(c 7.0, \mathrm{CHCl}_{3}\right)$. ${ }^{1} \mathrm{H}$ NMR $\left(\mathrm{C}_{6} \mathrm{D}_{6}\right): \delta_{\mathrm{H}} 0.8\left(3 \mathrm{H}, \mathrm{d},{ }^{3} J_{\mathrm{HH}}=7 \mathrm{~Hz}\right), 0.88\left(3 \mathrm{H} \mathrm{d},{ }^{3} J_{\mathrm{HH}}=7 \mathrm{~Hz}\right), 0.89\left(3 \mathrm{H}, \mathrm{d},{ }^{3} J_{\mathrm{HH}}=7 \mathrm{~Hz}\right)$, 
$0.90\left(3 \mathrm{H}, \mathrm{d},{ }^{3} \mathrm{~J}_{\mathrm{HH}}=7 \mathrm{~Hz}\right), 0.91\left(3 \mathrm{H}, \mathrm{d},{ }^{3} \mathrm{~J}_{\mathrm{HH}}=7 \mathrm{~Hz}\right), 0.8-1.65\left(16 \mathrm{H}, \mathrm{m}, \mathrm{CH}_{2} \mathrm{C}\right), 2.15-2.05(5 \mathrm{H}, \mathrm{m}$, $\left.\mathrm{PCH}_{2}+\mathrm{CH} 2+\mathrm{CH}\right), 2.4\left(1 \mathrm{H}, \mathrm{dd},{ }^{2} J_{\mathrm{HH}}=5.1 \mathrm{~Hz},{ }^{3} J_{\mathrm{HH}}=2.1 \mathrm{~Hz}, \mathrm{CH}^{\mathrm{a}} \mathrm{O}\right), 3.0\left(1 \mathrm{H}, \mathrm{dd},{ }^{2} J_{\mathrm{HH}}=5.1 \mathrm{~Hz}\right.$, $\left.{ }^{3} J_{\mathrm{HH}}=4 \mathrm{~Hz}, \mathrm{CH}^{\mathrm{b}} \mathrm{O}\right), 3.0(1 \mathrm{H}, \mathrm{m}, \mathrm{CHO}), 4.24(2 \mathrm{H}, \mathrm{m}, \mathrm{CHOP}) .{ }^{31} \mathrm{P} \mathrm{NMR}\left(\mathrm{CDCl}_{3}\right), \delta_{\mathrm{P}} 25.3$. Anal. Calcd for $\mathrm{C}_{23} \mathrm{H}_{43} \mathrm{O}_{4} \mathrm{P}: \mathrm{C}, 66.64 ; \mathrm{H}, 10.45 ; \mathrm{P}, 7.47$. Found: C, 66.34; H, 10.27; P, 7.11.

$\operatorname{Di}(1 R, 2 S, 5 R)$-menthyl (2R)-3-azido-2-hydroxypropylphosphonate (10b). To a solution of 2,3-epoxypropylphosphonate $\mathbf{9 b}(0.5 \mathrm{~g}, 1.2 \mathrm{mmol})$ in $7 \mathrm{ml}$ of methanol was added the sodium azide $(0.188 \mathrm{~g}, 2.89 \mathrm{mmol})$ and ammonium chloride $(0.115 \mathrm{~g}, 2.15 \mathrm{mmol})$. The mixture was refluxed for $4 \mathrm{~h}$. Then the solvent was evaporated under vacuum. The residue was dissolved in ethyl acetate and the solution was washed with water. The organic layer was separated, dried with $\mathrm{Na}_{2} \mathrm{SO}_{4}$. and concentrated to give $\mathbf{1 0 b}$ as a colorless oil. Yield: $96 \%$. $[\alpha]_{\mathrm{D}}{ }^{20}-74.2(c$ 2.5, $\left.\mathrm{CHCl}_{3}\right) .{ }^{1} \mathrm{H}$ NMR $\left(\mathrm{C}_{6} \mathrm{D}_{6}\right), \delta_{\mathrm{H}} 0.79,\left(3 \mathrm{H}, \mathrm{d},{ }^{3} J_{\mathrm{HH}}=7 \mathrm{~Hz}, \mathrm{CH}_{3}\right), 0.81\left(3 \mathrm{H}, \mathrm{d},{ }^{3} J_{\mathrm{HH}}=7 \mathrm{~Hz}, \mathrm{CH}_{3}\right), 0.91$ $\left(3 \mathrm{H}, \mathrm{d},{ }^{3} J_{\mathrm{HH}}=7 \mathrm{~Hz}, \mathrm{CH}_{3}\right), 0.92\left(3 \mathrm{H}, \mathrm{d},{ }^{3} J_{\mathrm{HH}}=7 \mathrm{~Hz}, \mathrm{CH}_{3}\right), 0.93\left(3 \mathrm{H}, \mathrm{d},{ }^{3} J_{\mathrm{HH}}=7 \mathrm{~Hz}, \mathrm{CH}_{3}\right), 0.94$ $\left(3 \mathrm{H}, \mathrm{d},{ }^{3} \mathrm{~J}_{\mathrm{HH}}=7 \mathrm{~Hz}, \mathrm{CH}_{3}\right), 1.0-2.0\left(16 \mathrm{H}, \mathrm{m}, \mathrm{CH}_{2} \mathrm{C}\right), 1.8(2 \mathrm{H}, \mathrm{m}, \mathrm{PCH}), 3.15\left(2 \mathrm{H}, \mathrm{m}, \mathrm{CH}_{2} \mathrm{~N}\right), 4.05$ $(2 \mathrm{H}, \mathrm{m}, \mathrm{CHO}), 4.14(2 \mathrm{H}, \mathrm{m}, \mathrm{C} \underline{\mathrm{HOH}}+\mathrm{OH}) .{ }^{31} \mathrm{P} \mathrm{NMR}\left(\mathrm{CDCl}_{3}\right), \delta_{\mathrm{P}} 27.4$. IR: $v_{\max } 2120 \mathrm{~cm}^{-1}\left(\mathrm{~N}_{3}\right)$. Anal. Calcd for $\mathrm{C}_{23} \mathrm{H}_{44} \mathrm{~N}_{3} \mathrm{O}_{4} \mathrm{P}: \mathrm{C}, 60.37 ; \mathrm{H}, 9.69 ; \mathrm{N}, 9.18$. Found $\mathrm{C}, 60.28 ; \mathrm{H}, 9.57 ; \mathrm{N}, 8.84$

Diethyl (2R)-2-hydroxy 3-azidopropylphosphonate (10a). Compound 10a was prepared analogously to 10b. Yield: 90\%, yellow oil; $v_{\max }$ (liquid film) 3681, 2984, 2105, 1225, 1099, 967 $\mathrm{cm}^{-1} ;{ }^{1} \mathrm{H}$ NMR $\left(\mathrm{C}_{6} \mathrm{D}_{6}\right): \delta_{\mathrm{H}} 1.23\left(6 \mathrm{H}, \mathrm{t},{ }^{3} \mathrm{~J}_{\mathrm{HH}}=7.0 \mathrm{~Hz}, \mathrm{CH}_{3},\right), 1.87\left(2 \mathrm{H}, \mathrm{m}, \mathrm{CH}_{2} \mathrm{P}\right), 3.24(2 \mathrm{H}, \mathrm{m}$, $\left.\mathrm{CH}_{2} \mathrm{~N}_{3}\right), 3.6(1 \mathrm{H}, \mathrm{br}, \mathrm{OH}), 4.03\left(5 \mathrm{H}, \mathrm{m}, \mathrm{OCH}_{2}\right.$ and $\left.\mathrm{C} \underline{\mathrm{HOH}}\right) .{ }^{31} \mathrm{P} \mathrm{NMR}\left(\mathrm{CDCl}_{3}\right), \delta_{\mathrm{P}} 29.5$. IR: $v_{\max }$ $1225(\mathrm{P}=\mathrm{O}), 2105\left(\mathrm{~N}_{3}\right), 3336(\mathrm{OH})$. Anal. Calcd for $\mathrm{C}_{7} \mathrm{H}_{16} \mathrm{~N}_{3} \mathrm{O}_{4} \mathrm{P}: \mathrm{C}, 35.45 ; \mathrm{H}, 6.80 ; \mathrm{P}, 13.06 \%$. Found C, 35.30; H, 6.71; P, 12.99

Diethyl (2S)-aziridine-2-yl-propylphosphonate (12a). To a solution of diethyl-(2S)-2-hydroxy3-azidopropylphosphonate 10a $(1.487 \mathrm{~g}, 6.27 \mathrm{mmol})$ in $45 \mathrm{ml}$ of toluene was added tryphenylphosphine $(1.65 \mathrm{~g}, 6.29 \mathrm{mmol})$. The reaction mixture was stirred at room temperature for 1-2 hr and was refluxed for $1 \mathrm{~h}$. The solvent was removed under reduced pressure and diethyl ether was added to the residue. The precipitate was filtered off, the filtrate was evaporated and the residue was distilled under vacuum to afford 20 as a colorless liquid. Yield: 60\%, bp 92-93 ${ }^{\circ} \mathrm{C}(0.07 \mathrm{~mm} \mathrm{Hg}) .{ }^{1} \mathrm{H} \mathrm{NMR}\left(\mathrm{C}_{6} \mathrm{D}_{6}\right): \delta_{\mathrm{H}} 1.166\left(3 \mathrm{H}, \mathrm{t}, J_{\mathrm{HH}}=7.0, \mathrm{CH}_{3}\right), 1.171\left(3 \mathrm{H}, \mathrm{t}, J_{\mathrm{HH}}=7.0 \mathrm{~Hz}\right.$, $\left.\mathrm{CH}_{3}\right), 1.13-1.18\left(1 \mathrm{H}, \mathrm{m}, \mathrm{CH}_{2} \mathrm{~N}\right), 1.43-1.52\left(1 \mathrm{H}, \mathrm{m}, \mathrm{CH}_{2} \mathrm{P}\right), 1.55\left(1 \mathrm{H}, \mathrm{d}, J_{\mathrm{HH}}=5.4 \mathrm{~Hz}, \mathrm{CH}_{2} \mathrm{~N}\right)$, 1.6-1.73 $\left(1 \mathrm{H}, \mathrm{m}, \mathrm{CH}_{2} \mathrm{P}\right), 1.93(1 \mathrm{H}, \mathrm{m}, \mathrm{CHN}), 3.82-4.01\left(4 \mathrm{H}, \mathrm{m}, \mathrm{CH}_{2}\right) .{ }^{13} \mathrm{C} \mathrm{NMR}\left(\mathrm{CDCl}_{3}\right), \delta_{\mathrm{C}}$ 61.98, 61.91, 31.46 (d, $J=142.7 \mathrm{~Hz}), 25.65,24.58,16.83,16.76{ }^{31} \mathrm{P} \mathrm{NMR}\left(\mathrm{CDCl}_{3}\right), \delta_{\mathrm{P}} 29.0$. Anal. Calcd for $\mathrm{C}_{7} \mathrm{H}_{16} \mathrm{NO}_{3} \mathrm{P}: \mathrm{C}, 43.52 ; \mathrm{H}, 8.35 ; \mathrm{N}, 7.25 ; \mathrm{P}, 16.03$. Found $\mathrm{C}$, 43.48; H, 8.29; N, 7.23; P, 16.00 .

\section{References}

1. Hildebrand, R. L.; Henderson, T. O. In The Role of Phosphonates in Living Systems, Hildebrand, R. L.,Ed., Boca Raton: Chem. Rubber, 1983; p 5.

2. Kolodiazhnyi, O. I. Tetrahedron: Asymmetry 2005, 16, 3295. 
3. Fields, S.C. Tetrahedron 1999, 55, 12, 237.

4. (a) Kolodiazhnyi, O.I., In Advances in Asymmetric Synthesis, A. Hassner Ed. London: JAI Press, 1998, Vol. 3, pp. 273-357. (b) Nesterov V. Ph.D. Thesis. Kiev, IBONCH, 2007.

5. Kolodiazhnyi, O. I. Tetrahedron: Asymmetry 1998, 9, 1279.

6. Meier, C.; Laux, W. H. G. Tetrahedron: Asymmetry 1995, 6, 1089.

7. Meier, C.; Laux, W. H. G., Tetrahedron 1996, 52, 589.

8. Kitamura, M.; Tokunaga, M.; Pham, T.; Lubell, W. D.; Noyori, R. Tetrahedron Lett. 1995, 36, 5769.

9. Yokomatsu, T.; Hayakawa, Y.; Suemune, K.; Kihara, T.; Soed, S.; Shimeno, H.; Shibuya, S. Bioorg. Med. Chem. Lett. 1999, 9, 2833.

10. Gajda, T. Tetrahedron: Asymmetry 1994, 5, 1965.

11. Chen, R.; Breuer, E. J. Org. Chem. 1998, 63, 5107.

12. Yokomatsu, T.; Hayakawa, Y.; Suemune, K.; Kihara, T.; Soed, S.; Shimeno, H.; Shibuya, S. Bioorg. Med. Chem. Lett. 1999, 9, 2833.

13. Ordonez, M.; de la Cruz, R.; Fernandez-Zertuche, M. M.; Munoz-Hernandez, M.-A. Tetrahedron: Asymmetry 2002, 13, 559.

14. Kolodiazhna, A. O.; Kukhar, V. P.; Chernega, A. N., Kolodiazhnyi, O. I. Tetrahedron: Asymmetry 2004, 15, 1961.

15. Nesterov, V. V.; Kolodiazhnyi, O. I. Tetrahedron: Asymmetry 2006, 17, 1023.

16. Nesterov, V. V.; Kolodiazhnyi, O. I. Synlett 2007, 2400.

17. Ordonez, M.; De la Cruz-Cordero, R.; Fernandez-Zertuche, M.; Munoz-Hernandez, M. A.; Garcia-Barradas, O. Tetrahedron: Asymmetry 2004, 15, 3035.

18. a) Umino, N.; Iwakuma, T.; Itoh, N. Chem Pharm Bull. 1979, 27, 1479. (b) List, B. Tetrahedron 2002, 58, 5573.

19. Morita, T.; Okamoto, Y.; Sakurai, H. Tetrahedron Lett. 1978, $28,2523$.

20. (a) Sasai, H.; Arai, S.; Tahara, Y.; Shibasaki, M. J. Org. Chem. 1995, 60, 6656. (b) Sasai, H.; Bougauchi, M.; Aral, T.; Shibasaki,M. Tetrahedron Lett. 1997, 38, 2717.

21. Nesterov, V. V.; Grishkun, E. V.; Kolodyazhnyi, O. I. Russ. J. Gen. Chem. 2004, 74, 1947.

22. Nesterov, V. V.; Kolodyazhnyi, O. I. Russ. J. Gen. Chem.. 2005, 75, 1161.

23. Seyden-Penne, J., Reduction by the Alumino- and Borohydrides in Organic Synthesis, New York: Wiley, 1997; p 6.

24. Kolodiazhnyi, O. I. Tetrahedron 2003, 59, 5923.

25. Blazis, V. J.; Koeller, K. J.; Spilling, C. D. J. Org. Chem. 1995, 60, 931.

26. Majewska, P.; Kafarski, P.; Lejczak, B. Tetrahedron: Asymmetry 2006, 17, 2870.

27. Kielbasinski, P.; Luczak, J.; Mikolajczyk, M. J. Org. Chem. 2002, 67, 7872.

28. (a) Keglevich, G.; Tóth V. R.; Drahos, L. Heteroatom Chem. 2011, 22, 15. (b) Keglevich, G.; Szekrényi, A. Lett.Org.Chem. 2008, 5, 616.

29. (a) Yuan, C.; Wang, K. Li, Z. Heteroatom. Chem. 2001, 12, 551. (b) Wang, K.; Zhang, Y.; Yuan, C. Org. Biomol.Chem. 2003, 1, 3564

30. Wroblewski, A. E.; Halajewska-Wosik, A. Eur. J. Org. Chem. 2002, 2758. 
31. Yokomatsu, T.; Yamagishi, T.; Shibuya, S. Tetrahedron: Asymmetry 1993, 4, 1779.

32. Zymanczyk-Duda, E.; Lejczak B.; Kafarski, P.; Grimaud, J.; Fischer, P. Tetrahedron 1995, $51,11809$.

33. Kolodiazhna, A. O.; Kukhar, V. P.; Kolodiazhnyi, O. I. Russ. J. Gen. Chem. 2006, 74, 1342. 